\title{
CEOs' International Work Experience and Compensation
}

\author{
Stefan Schmid ${ }^{1}$ (D) . Sebastian Baldermann ${ }^{1}$ (D)
}

Received: 23 April 2020 / Revised: 5 March 2021 / Accepted: 11 March 2021 /

Published online: 11 August 2021

(c) The Author(s) 2021

\begin{abstract}
In this paper, we study the effect a CEO's international work experience has on his or her compensation. By combining human capital theory with a resource dependence and a resource-based perspective, we argue that international work experience translates into higher pay. We also suggest that international work experience comprises several dimensions that affect CEO compensation: duration, timing and breadth of stays abroad. With data from Europe's largest stock market firms, we provide evidence that the longer the international work experiences and the more numerous they are, the higher a CEO's compensation. While, based on our theoretical arguments, we expect to find that later international work experiences pay off for CEOs, our empirical analysis shows that earlier international work experiences are particularly valuable in terms of compensation. In addition, our data support the argument that maturity allows a CEO to take advantage of the skills, knowledge and competencies obtained via international experience- and to receive a higher payoff. With our study, we improve the understanding of how different facets of a CEO's background shape executive remuneration.
\end{abstract}

Keywords Executive compensation · Human capital theory $\cdot$ Resource dependence theory $\cdot$ Resource-based view $\cdot$ International top managers $\cdot$ International experience $\cdot$ International work experience $\cdot$ Maturity $\cdot$ Cultural distance

\section{Introduction}

Multinational corporations (MNCs) need top managers who are able to navigate in diverse environments. Hence, it has repeatedly been emphasized that top managers with international experience are beneficial for MNCs (Daily et al. 2000; Magnusson

Stefan Schmid

sschmid@escp.eu

Sebastian Baldermann

sbaldermann@escp.eu

1 Department of International Management and Strategic Management, ESCP Business School Berlin, Heubnerweg 8-10, 14059 Berlin, Germany 
and Boggs 2006; Ng et al. 2009). David Jones, Senior Managing Director at specialized recruitment firm Robert Half International, recently stated, "Aside from being personally rewarding, leaders who display diversified career experience-whether by working in global markets or by undertaking international assignments-generally have a better understanding of how organizations operate internationally [...]" (The CEO Magazine 2019). In this respect, we can expect that a top manager's international experience affects not only his or her individual development, but also his or her compensation. Firms continue to stress that only attractive compensation schemes allow them to hire and/or retain individuals who are suitable for top management positions in an international context (Consultancy.eu 2018; The Guardian 2019).

In the present paper, we combine human capital theory with resource perspectives of the firm, i.e., resource dependence theory and the resource-based view. We propose that international work experience (IWE) affects a CEO's human capital, and hence his or her skills, knowledge and competencies. As these skills, knowledge and competencies constitute valuable resources for a firm, a CEO with such resources can influence compensation (setting) in his or her favor. We argue that not only the duration, but also the timing and breadth of international work experience matter for compensation. In terms of duration, we consider how long international work experiences have lasted. Timing relates to the question of how far international experiences date back or how recent they are. Breadth reflects how many different stays abroad were completed.

As we distinguish between different dimensions of international experience, we respond to recent calls in literature to refine and improve our understanding of international work experience (Le and Kroll 2017; Reiche et al. 2019; Rickley 2019; Takeuchi and Chen 2013). In doing so, we move beyond existing literature that focused exclusively on the mere existence or the duration of international work experience (Conyon et al. 2019; Schmid et al. 2018). In our paper, we also acknowledge that the relationship between international work experience and compensation is contingent on other individual-level characteristics of the CEO. In this regard, we focus on CEOs' maturity. By drawing on literature about maturity, we theorize that maturity moderates the relationships between different dimensions of international work experience and compensation.

We empirically test our hypotheses with a sample of the CEOs from the 500 largest firms in Europe (see also Schmid et al. 2018). Based on detailed, hand-collected data on CEOs' careers, we analyze each individual's international work experiences completed prior to being appointed to the CEO position. Our regression analyses provide empirical evidence that the longer and the more often a CEO has stayed abroad in his or her career, the higher the compensation level that can be realized. While our hypothesized relationship emphasizes the value of late international work experience, our empirical results, in contrast, highlight that earlier international work experience is associated with higher compensation. Our moderated regression analyses show a positive, moderating influence of a CEO's maturity. We also carry out additional analyses, in which we combine duration, timing and breadth of stays abroad into composite indices, in order to investigate the joint effects of the dimensions of international work experience. Moreover, in refined analyses, we include the cultural distance (CD) to the 
countries where a CEO gained his or her international experience. We may thus infer that working in countries with higher cultural distance pays off more than work experience in countries with lower cultural distance.

Through our paper, we add to research on CEOs, their international work experiences, and their compensation in an MNC context (Career Trend 2017; Van Essen et al. 2015). Among all top executive positions, the CEO position is the most important and publicly exposed one, but we still lack insights into the impact of CEO characteristics, such as international work experience, on an outcome like compensation (see, for instance, Bebchuk et al. 2011; Bruton et al. 1997). With some notable exceptions (Carpenter et al. 2001; Randøy and Nielsen 2002; Schmid and Altfeld 2018), previous literature on international work experience predominantly focuses on firm-level consequences of CEOs' stays abroad (see, for instance, Daily et al. 2000; Le and Kroll 2017; Slater and Dixon-Fowler 2009). In general, while many studies have already investigated factors that influence compensation at the country level, the industry level and the firm level (Kostiuk, 1990; Porac et al. 1999; Tosi and Greckhamer 2004), literature on individual-level determinants is still relatively scarce.

Thus, we contribute herein to International Business (IB), upper echelons, and corporate governance literature. First, by building on human capital theory, resource dependence theory and the resource-based view, we theorize not only about the value of international work experience, but also the actual way it enables CEOs to influence their compensation. This is an advancement compared to existing studies (Carpenter et al. 2001; Conyon et al. 2019; Schmid and Altfeld 2018), as we attempt to unpack the mechanism that allows CEOs to receive a higher payoff in relation to stays abroad. By differentiating between duration, timing and breadth, we argue that several dimensions of international work experience determine the value of its embedded human capital. While prior literature has largely neglected individual-level influences on CEO compensation, we also highlight the relevance of contingency factors, by describing the positive effects of individual maturity as a moderator (which to date has often had a negative connotation, e.g., Simpson et al. 2002). Second, through our empirical results, we emphasize the importance of early international experience and associated general-purpose human capital, whereas prior literature has often stressed the merits of experience (abroad) in general or late experiences (abroad) and the so-called 'taskspecific' human capital (Carpenter et al. 2001; Schmid and Altfeld 2018; Schulz et al. 2013). Herein, we add novel empirical insights into the value of the experience gained in different phases of an individual's life. Third, practitioners who wish to grasp the monetary value of stays abroad can benefit from our study, since our paper increases firms' and/or compensation consultants' understanding of what makes internationally seasoned CEOs 'more expensive'. 


\section{Theoretical Background and Hypotheses}

\subsection{International Work Experience and Compensation}

\subsubsection{International Work Experience: The Human Capital Theory Perspective}

Human capital theory helps us to argue why international work experience matters. Its basic assumption is that an individual's characteristics transfer into his or her ability to perform certain tasks or jobs (Blaug 1976; Dobbs et al. 2008; Nafukho et al. 2004). In line with existing studies, we assume that international work experience influences individuals in general and contributes to human capital in particular (Inkson et al. 1997; Magnusson and Boggs 2006; Takeuchi et al. 2005). Many studies have shown that international work experience shapes the values, attitudes, beliefs and behaviors of top managers such as CEOs (Carpenter et al. 2001; Daily et al. 2000; Slater and Dixon-Fowler 2009). Furthermore, scholars have suggested that international work experience provides CEOs in MNCs with important capabilities required to perform their tasks (David and Lopez 2001; Mahoney and Kor 2015) and to make wide-reaching decisions, also in an international context (Jiang et al. 2018; Lepak and Snell 1999).

We argue that work experience abroad is linked to increases in a CEO's human capital. By staying abroad, (future) top managers accumulate valuable skills, knowledge and competencies (Carpenter et al. 2001; Herrmann and Datta 2005; Jones 2013; Roth, 1995), which in turn helps them lead firms that operate abroad (Lu and Beamish 2001; Sambharya 1996) and enhances innovativeness, creativity or entrepreneurial orientation (Godart et al. 2015; Maddux and Galinsky 2009; Maddux et al. 2020; Schlepphorst et al. 2020). In other words, international work experience is positively related to the development of the kind of human capital that is necessary to cope with the challenges in an increasingly globalized world (Gupta and Govindarajan 2002; Knight and Cavusgil 2004; Peng et al. 2015). Human capital obtained through international work experience also improves top managers' ability to adapt to and proactively operate in diverse environments (Haas 2006; Ng et al. 2011; Tung, 1998). Moreover, international work experience is a crucial characteristic of CEOs in MNCs, as it can favorably affect firmlevel outcomes such as strategies or performance (Athanassiou and Nigh 2002; Demir and Söderman 2007; Lee and Roberts 2015; Nielsen 2010; Sambharya 1996).

However, we do not assert that each international work experience is of equal value. Rather, we suggest that its value is also determined by the type of human capital acquired with the help of the stay abroad. Several scholars argue that different types of human capital exist (Datta and Iskandar-Datta 2014; Gibbons and Waldman 2004; Wright and McMahan 2011). For instance, based on Becker's (1964) work, Gibbons and Waldman (2004) distinguish between task-specific human capital and general-purpose human capital. Human capital that is "specific to the tasks being performed" reflects the concept of "learning by doing" (Gibbons and Waldman 2004). It may be linked to a particular occupation or a 
functional background, but it can be portable across jobs (Datta and IskandarDatta 2014; Gathmann and Schönberg 2010; Gibbons and Waldman 2004). Promotions to other positions/jobs can avoid the underutilization of task-specific human capital or even support the acquisition of task-specific human capital (Lazear, 2009; Prendergast 1993). General-purpose human capital comprises skills, knowledge and competencies that are generally useful (Gathmann and Schönberg 2010; Neal 1995; Slaughter et al. 2007; Wright and McMahan 2011). This type of human capital is accumulated over the course of an individual's life and does not need to be tied to a specific organization or position (Custódio et al. 2013; Mishra 2014).

\subsubsection{International Work Experience as a Resource: Combining Human Capital Theory with Resource Dependence Theory and the Resource-Based View}

We suggest that individual-level human capital contributes to the development of a "human capital resource" (Ployhart and Moliterno 2011). Accordingly, we align the human capital resulting from international work experiences with resource dependence theory, as well as the resource-based view of the firm (Hillman et al. 2000; Kraaijenbrink 2011). Incorporating both resource dependence theory and the resource-based view of the firm enables us to move beyond prior literature and unpack the mechanism via which international work experience leads to higher pay. Taking a resource dependence perspective, we argue that firms want to reduce uncertainty in complex environments with their human capital base (Nienhüser 2008; Pfeffer and Salancik 1978). Following the resource-based view of the firm, firms wish to build their competitive advantage on the human capital base they have established (Wernerfelt 1984; Wright et al. 2001).

As suggested by resource dependence literature, firms can draw on top managers, such as CEOs, to respond to challenges in their environment (Hillman et al. 2000). Since MNCs depend on human capital resources resulting from international work experience, they will attempt to attract internationally seasoned CEOs (Daily et al. 2000). If human capital resulting from international work experience is not (sufficiently) available within the MNC, the firm will draw on external human capital resources (Campbell et al. 2012; Chen et al. 2016; Hillman et al. 2009; Peng et al. 2015); for instance, in such a case, a firm might hire individuals with international experience from its environment, i.e., from its competitors (Brockman et al. 2016; Campbell et al. 2012; Jongjaroenkamol and Laux 2017). Benefiting from the international experience of their CEOs, MNCs improve their ability to reduce the environmental uncertainty with which they are confronted (Hillman et al. 2009). In other words, when a human capital resource related to international work experience has been obtained and is built up in the focal firm, the MNC improves its competitive position in the international environment in which it operates (Davis and Cobb 2010; Drees and Heugens 2013).

Consistent with the resource-based interpretation of human capital (Kraaijenbrink 2011; Wright et al. 2001), MNCs base their competitive advantage on a combination of specific internal resources (Barney et al. 2001; Wernerfelt 1984). In this regard, we can argue that MNCs also draw on their CEOs' international work 
experience (Peng 2001). MNCs strive to have top managers with international experience, as they possess valuable intangible assets that the firm can access and that it does not wish to lose (Hitt et al. 2001; Roth 1995; Wright et al. 2001). Furthermore, MNCs also have an interest in developing the human capital of employees, including that of (potential) CEOs, internally (Cheong et al. 2019; Contractor and Mudambi 2008; Dickmann and Harris 2005). Some MNCs seek to build up their human capital resources, for instance, by initiating the international flow of personnel with expatriate programs for executives and by proactively supporting key employees in expanding their international work experience (Bonache et al. 2001; Heckman 2000; Lepak and Snell, 1999; Ng et al. 2011; Ramaswami et al. 2016). By developing the leadership skills of (future) top managers in an international context, firms can rely on individuals who are able to deal with not only a challenging external environment, but also the intricate cultures and expectations that prevail in many large organizations operating across borders (McNulty and De Cieri 2011; Ng et al. 2011; Takeuchi et al. 2009; Windsor, 2009). As the focal firm strives to keep and develop the human capital resource related to international work experience, it thus sustains or even further enhances its competitive advantage over other firms (Barney et al. 2001; Peteraf 1993).

\subsubsection{Human Capital Resources and Compensation}

International work experiences can help CEOs to signal the skills, knowledge and competencies that are beneficial for the international context (Falato et al. 2015) and thus convey important human capital for such a CEO who heads an MNC (Gupta and Govindarajan 2002; Knight and Cavusgil 2004). We theorize that CEOs can capitalize on international work experience and that they should expect to receive significant financial returns (see, for instance, Becker 2006; Peng et al. 2015). We build our argument on Peng et al. (2015, p. 118), who claim that "how much boards decide to compensate CEOs can be conceptualized as a valuation process of how boards value CEOs' capabilities_embodied in their human capital [...]". This suggests that those in charge of compensation observe CEOs' characteristics and link these to the human capital resource the CEO brings to the firm-which can cause favorable outcomes, for instance, in terms of firm performance (Volonté and Gantenbein 2016). Several perspectives help to shed light on why international work experience as a human capital resource translates into compensation.

First, the human capital of CEOs has been labeled not only as valuable, but also as a rare and inimitable resource: Several studies suggest that differences in a CEO's human capital result in pay differences, because specific assets are scarce in managerial labor markets (Harris and Helfat 1997; Mackey et al. 2014). Skills, knowledge and competencies associated with international work experience, and especially extensive international work experience, are not easy to obtain and cannot be imitated, not least because they are often accumulated over the course of an entire professional career spanning across many decades (Biemann and Wolf 2009; Daily et al. 2000; Magnusson and Boggs 2006). In the past, many CEOs adhered to a national career pattern (Hooghiemstra et al. 2019; Van Veen and Marsman 2008), which led to a relatively low supply of CEOs with substantive international 
work experience. However, firms still depend on the rare and scarce human capital resources of those top managers (who are nowadays mostly in their 50s and 60s). Hence, MNCs seeking internationally experienced CEOs, in order to gain a competitive advantage, have to develop incentives and pay for their respective skills, knowledge and competencies.

Second, internationally seasoned CEOs have more structural and social influence over decisions made in firms (Otten et al. 2012). Previous studies have suggested that the demographic characteristics of the CEO directly enter the compensationsetting process, i.e., they influence decisions made by the compensation committee of the respective firm (Hermanson et al. 2012; Main et al. 1995; Westphal and Zajac 1995). When (re)negotiating compensation, CEOs with valuable prior experience are in a more powerful position, and this allows them to influence their compensation (Tien et al. 2013). Within their focal firms, CEOs may even affect (the selection of) those who are responsible for setting compensation (Lippert and Porter 1997). It has also been shown that powerful top managers can influence not only the amount, but also, for instance, the structure of pay (Bebchuk et al. 2001; Van Essen et al. 2015). Hence, CEOs can use their structural and social power to 'leverage' the value of their international work experience such that it is reflected extensively in their compensation packages. Put differently, they can influence compensation decisions in such a way that their human capital resource related to international work experience is paid for. We thus argue that CEOs with international work experience receive higher pay, because firms are willing to pay for the valuable, rare and inimitable human capital resources of the CEOs they wish to hire and/or because internationally seasoned CEOs can influence the decision-making process in terms of compensation. In other words, because firms depend on CEOs' human capital resources and want to use them to their advantage, they 'allow' top managers to influence compensation setting.

\subsection{The Role of Different Dimensions of International Work Experience}

We propose that international experience consists of several dimensions, and so we differentiate between duration, timing and breadth of international experience. This approach has several merits. While the duration of an international experience is important and allows for assessing how long somebody has been exposed to foreign environments, it does not capture all aspects that make stays abroad worthwhile. In addition to duration, timing has been highlighted as a relevant dimension of international experience (Chen et al. 2016; Takeuchi and Chen 2013). Timing is particularly important, as international experience during different stages of a career can have differing impacts on values, attitudes, beliefs or skills, knowledge and competencies-which cannot be captured by the established measure of duration (Takeuchi and Chen 2013). Furthermore, analyzing the duration of international experience does not enable an understanding of whether an individual has stayed abroad only once or repeatedly (Tesluk and Jacobs 1998). The latter, which we label 'breadth', however, is an important quality of experience; it reflects whether somebody has had the opportunity to perform and practice abroad not only once, but several times and 
in different environments (Ford et al. 1992; Tesluk and Jacobs 1998), and to develop a more heterogeneous, 'broader' mindset (Nadkarni et al. 2011). None of this is reflected by duration or timing. By considering timing and breadth next to duration, we want to incorporate the most commonly discussed dimensions of international experience (Tesluk and Jacobs 1998; Takeuchi and Chen 2013).

\subsubsection{Duration}

Consistent with existing studies (Carpenter et al. 2001), we conceptualize 'duration' as the time a top manager has spent working in other countries, i.e., 'how long' the top manager stayed abroad. In this context, the importance of 'duration' has also been evoked in managerial practice. For instance, Henry McKinnell, former CEO of Pfizer Inc., stressed that "[...] to get the benefits, you need to stay long enough to make some mistakes and correct those mistakes" (Chief Executive 2004).

We propose that a CEO's individual international human capital increases in line with the duration of his or her prior international work experiences (Carpenter et al. 2001; Oxelheim and Randøy 2005). Thus, the longer the stays abroad, the more extensive the stock of international human capital that can be built by CEOs, i.e., the more skills, knowledge and competencies can be accumulated. Consequently, the longer the international work experiences of a CEO lasted, the more valuable the intangible assets for the MNC (Kraaijenbrink 2011). Since skills, knowledge and competencies are desired by MNCs (Ang and Van Dyne 2015; Igarashi and Saito 2014; Ng et al. 2011), they will particularly search for or try to retain CEOs with a high level of human capital derived from lengthy international work experiences. And because firms depend on and, accordingly, value and reward the individual human capital resource the CEO brings to the firm, we expect the duration of international work experiences to affect his or her compensation positively (Björkman et al. 2004; Carpenter et al. 2001). Hence, we hypothesize the following:

Hypothesis 1: There is a positive relationship between the duration of a CEO's international work experiences and a CEO's compensation level such that the longer the international work experiences of a CEO have lasted, the higher is the CEO's compensation level.

\subsubsection{Timing}

We suggest that next to duration, timing can be a decisive factor in determining the value of international work experiences. Hence, we claim that it matters at what point in time an international work experience took place. Kenneth 'Hap' Klopp, former owner and CEO of The North Face, once stated, "Most future CEOs move into substantial operational roles, typically running the largest division or the most important international business, before they get offered the top spot" (Hult 2020). This implies a temporal perspective on the value of international responsibilities, in which later international work experience (for instance, associated with being entirely in charge of business in relevant international markets) is especially valuable. 
We argue that this relates to the type of human capital international work experience delivers at different points in time. Whether an international work experience predominantly delivers general-purpose or task-specific human capital for CEOs depends on the time at which it has taken place. We expect late international work experiences to deliver task-specific human capital required for the CEO position in the form of very specific management and leadership skills developed while running an international business (Conyon et al. 2019; Daily et al. 2000; Gibbons and Waldman 2004). Moreover, late stays abroad are likely to give future CEOs the opportunity to work in responsible positions in foreign countries. These positions allow them to develop exactly those skills, knowledge and competencies associated with management and leadership qualities that are useful when heading an MNC. Thus, we argue that especially late international work experiences, i.e., those completed in temporal proximity to becoming a CEO, are rewarded by firms and pay off in terms of compensation (Conyon et al. 2019; Daily et al. 2000; Gibbons and Waldman 2004). We acknowledge that prior studies posit that both task-specific and generalpurpose human capital can affect compensation (Schulz et al. 2013); so in line with this reasoning, we do not claim that earlier international work experiences have no impact on CEO compensation. In fact, they can deliver general-purpose human capital, for instance by helping individuals to develop a general cross-cultural awareness (Gibbons and Waldman 2004; Harris and Helfat 1997; Le and Kroll 2017). However, we expect the task-specific human capital obtained with late international work experiences to be a stronger driver of CEO compensation. Therefore, we suggest that firms will financially reward those executives whose biographies are particularly skewed towards later international work experiences. We therefore hypothesize as follows:

Hypothesis 2: There is a positive relationship between the timing of a CEO's international work experiences and a CEO's compensation level such that the later a CEO's international work experiences have taken place, the higher is the CEO's compensation level.

\subsubsection{Breadth}

Furthermore, we expect the breadth of international work experiences to be a relevant determinant of compensation. Oliver Watson, Executive Board Director UK, USA and Canada at Michael Page, points out, "Companies are operating over so many international boundaries, so the more languages and experience with different cultures you can bring to a company, the more you can help expand its global reach" (Financial PageGroup 2019; Times 2013). The 'breadth' of international work experiences addresses the number of different international work experiences a top manager has had throughout his or her career, i.e., 'how often' he or she worked abroad.

The more international work experiences a CEO completes, the broader the stock of his or her skills, knowledge, and competencies (Carpenter et al. 2001; Jones 2013). International work experiences can be interpreted as individual-specific assets related to the human capital of the CEO (Kraaijenbrink 2011), which are valuable for the firm a CEO is managing (Hitt et al. 2001; Roth 1995; Wright et al. 2001). Each 
international work experience can be regarded as a unique asset that adds to the overall human capital resource of the CEO. The more varied international experiences a CEO has completed, the more he or she has been exposed to different cultures, business environments, etc., i.e., the more assets he or she accumulates (Conyon et al. 2019; Crossman and Clarke 2010). Accordingly, the human capital of the CEO increases in line with the number of international experiences he or she has in their armory (Kraaijenbrink 2011; Ng et al. 2011; Wright et al. 2001). For MNCs operating in a global environment, it is desirable to hire or retain a CEO with more assets related to international work experiences compared to their competitors. Moreover, larger numbers of international work experiences allow CEOs to compare and link general-purpose and task-specific skills obtained while staying abroad, which might help them to lead MNCs (Brymer et al. 2011; Gibbons and Waldman 2004; Tsoukas 1996; Weick 1995). Consequently, we expect firms to value a broad set of international work experiences in the form of compensation, and we hypothesize as follows:

Hypothesis 3: There is a positive relationship between the breadth of a CEO's international work experiences and a CEO's compensation level such that the more different stations of international work experience a CEO has completed, the higher is the CEO's compensation level.

\subsection{The Moderating Role of Maturity}

The association between CEOs' international work experience and compensation is not a self-contained process, but can be affected by further characteristics of the CEO. We argue here that a CEO's maturity influences the association between international work experience and compensation.

Maturity is the result of a learning process, i.e., individuals become more mature over the course of time (Argyris 1964, 1973; Herzberg et al. 1957). The maturity of individuals has been linked to several individual characteristics, for instance, it has been associated with independence, responsible behavior and orientation towards achieving goals (Blank et al. 1988; Hersey and Blanchard 1969; Sheldon et al. 2006). Moreover, maturity is also often assumed to be linked to one's capability to judge and make decisions (Steinberg and Cauffman 1996). The individual characteristics associated with maturity are highly relevant in a business context, which is why the concept of maturity has been broadly applied to studying firms and managers (Allen and Barnsley 1993; Diamond 1986; Grundstein 2008; Hunt and Saul 1975; Selmer 2001) as well as with regard to compensation (Hogan and McPheters 1980; McKnight and Tomkins 2004). In this respect, prior literature has predominantly stressed the direct impacts of maturity and related characteristics (Bal et al. 2008; Clark et al. 1996; Costanza et al. 2012; Drabe et al. 2015; Herr and Enderlein 1976; Hunt and Saul 1975; Kearney 2008; Kooij et al. 2011; Thompson and Phua 2012). In our paper, we add a new perspective and focus on the indirect, contingent influence maturity can have in this regard.

Literature on vocational behavior and careers has already suggested that maturity interacts with the exploitation of past experience in a work context (Heath 
1976; Savickas 2001; Super and Kidd 1979). As individuals become more mature, they are increasingly able to reflect on their life and career, which then allows them to categorize and evaluate adequately different kinds of experiences (Bandura 1986; Brymer et al. 2011; McKnight et al. 2000; Tsoukas 1996; Weick 1995). Accordingly, individuals learn to apply 'lessons' from their past experience to their current work situation. In our case, as CEOs become more mature, they comprehend and retrace their international experience, which in turn enables them to make proper use of the skills, knowledge and competencies obtained in association with international experience (Brymer et al. 2011). In other words, maturity allows CEOs to better access and utilize the human capital resource that was built throughout stays abroad. For instance, if a CEO improved his or her skills in dealing with different cultures in foreign countries, he or she would become more seasoned and experienced in applying these skills with increasing maturity. Maturity would thus enhance the value of the international experience, as it allows a CEO to translate better intercultural competence into actions and behaviors.

We argue that maturity interferes with the translation of international work experience into compensation (Pasupathi et al. 2006; Simpson et al. 2002). Behaviors that result from maturity are observed and evaluated by others-such as those responsible for setting compensation (Flouri and Buchanan 2002; Hogan and Roberts 2004; Sheldon and Kasser 2001). As mature CEOs make better use of their human capital resource built through international work experience, their skills, knowledge and competencies gained abroad are also perceived as being more extensive. Firms wishing to hire or retain an internationally seasoned CEO would thus (implicitly) appreciate maturity: As it enhances the perceived value of a (potential) CEO's international work experience, maturity puts him or her in a better bargaining position when (re)negotiating compensation. More mature CEOs can also exercise even more structural and social power to affect compensation setting in their favor, since they can better exploit their valuable characteristics (Otten et al. 2012). Accordingly, more mature CEOs can leverage the value of their international experience more effectively, thereby raising their remuneration to even higher levels.

In particular, maturity influences the translation of each of our dimensions of international work experience into compensation. First, longer duration of international work experience equips CEOs with a larger stock of skills, knowledge and competencies. Maturity as a contingent factor can unfold its positively moderating properties on the relationship between an extensive human capital base and the monetary outcome. Second, an increased maturity provides CEOs with better abilities to capitalize on international work experiences; it allows them to draw more profound and enhanced conclusions from their stays abroad, thus positively increasing the effect late (and, hence, recent) international experience has on compensation. Third, in relation to the dimension of breadth, a CEO's maturity facilitates a more differentiated base of human capital to unfold a positively moderating influence on compensation. In sum, maturity enhances the value of the human capital derived from duration, timing and breadth of international work experience, which in turn improves CEOs' compensation. We thus hypothesize as follows: 
Hypothesis 4a: The maturity of the CEO positively moderates the relationship between the duration of a CEO's international work experiences and a CEO's compensation level.

Hypothesis 4b: The maturity of the CEO positively moderates the relationship between the timing of a CEO's international work experiences and a CEO's compensation level.

Hypothesis 4c: The maturity of the CEO positively moderates the relationship between the breadth of a CEO's international work experiences and a CEO's compensation level.

Figure 1visualizes our research framework.

\section{Methodology}

\subsection{Data and Sample}

Our sample consists of the CEOs from the 500 largest firms in Europe at the end of 2013, as included in the Financial Times Europe 500 list. Focusing on large and listed firms as well as a European context has several merits. First, most FT Europe 500 firms are not only large, but also highly international; hence, they require competencies to deal with different international contexts. Accordingly, we may expect that they benefit from top managers who have stayed abroad and pay for the human capital resulting from this international experience (Daily et al. 2000; Hamori and

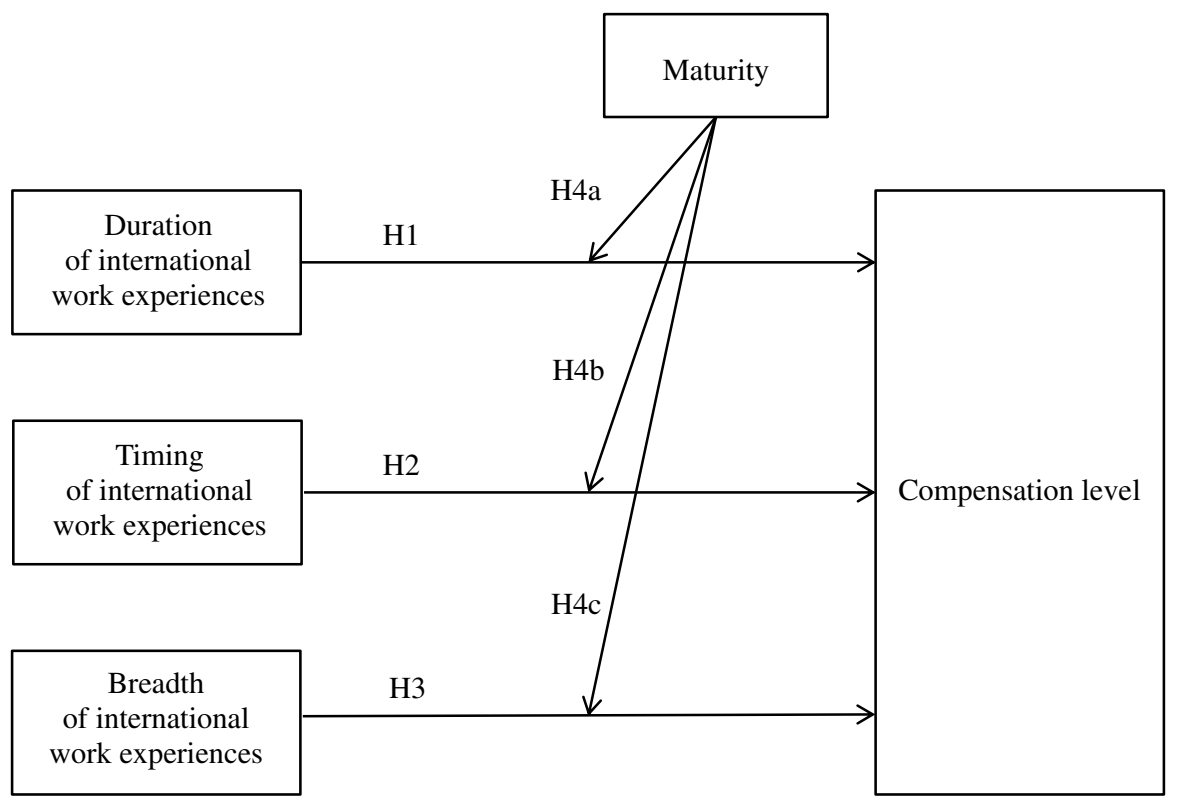

Fig. 1 Research framework 
Koyuncu 2011; Magnusson and Boggs 2006). Moreover, our focus on listed firms allows us to obtain detailed published information on CEOs, their compensation and firm data. Large and listed firms tend to release more information than smaller and non-listed firms (Ballas and Tzovas 2010; Point 2005). Investigating a European sample adds a new perspective to the study of executive compensation. Among prior studies, US samples still dominate (see, for instance, Carpenter et al. 2001; Kaplan 2008; Lin et al. 2013), which makes research with samples from other parts of the world, such as Europe, warranted.

The FT 500 list includes the largest stock market oriented European firms, mainly according to their market capitalization (see Financial Times 2015 for an overview). As some firms in our sample operate with dual CEOs, our initial sample comprises 507 individuals. CEO compensation data, firm and industry data were retrieved from Standard \& Poor's Capital IQ and Datastream. We gathered biographical information on the career paths of CEOs, including international work experiences, by hand-collecting data from various sources, such as BoardEx CVs, firm websites, and annual reports.

From our initial sample, we excluded 57 CEOs with a tenure, i.e., time in office as a CEO, of less than one year (at the end of 2013), because we did not want phenomena such as signing bonuses or partial-year compensation to distort our empirical results (Fernandes et al. 2013; Hill and Phan 1991). Of the remaining 450 CEOs, another 175 cases had to be dropped, due to unavailable data or missing information on international work experiences, on compensation or related to the moderator and control variables. Consequently, after having started with an initial sample of 507 CEOs with 2518 career experiences, we obtained a final sample of 275 CEOs with 1698 career experiences, i.e., 6.17 career experiences on average. There are several reasons for the high number of eliminated cases. First, we aim to record a CEO's entire career, including all of his or her experiences. Second, we require highly detailed data for the operationalization of duration, timing and breadth of international work experiences. For instance, we excluded each case as soon as any piece of biographical information on the duration, timing or breadth of a career experience was determined as missing. Third, we do not extrapolate values in the case of missing variables. The advantage of our procedure is that our final sample only contains CEOs for which we have complete biographic information on every international work experience.

\subsection{Dependent Variable}

For our dependent variable, we focus on total compensation. Studies have shown that individual characteristics, such as international work experience, can affect both fixed and variable components of executive compensation (Datta and Iskandar-Datta 2014; McKnight and Tomkins 2004; Qin 2012; Schmid and Wurster 2016). Consistent with prior studies and to avoid issues with heteroscedasticity, we apply logarithmic transformation to the total compensation data of CEOs (Benoit 2011; Datta and Iskandar-Datta 2014; Dyl 1988). 


\subsection{Independent Variables}

For the operationalization of the independent variables, we take into account all international work experiences a CEO has completed prior to his or her ultimate appointment. In line with prior literature, an experience is considered international if it has taken place outside of the country in which the focal firm's headquarters are located (Carpenter et al. 2001; Daily et al. 2000). International work experience involves being physically present abroad to fulfil work-related duties, i.e., the workplace and residence of the CEO must have been located in a foreign country. When differentiating between the duration, timing and breadth of international work experience, we relate to existing literature that has already measured (international) experience in a fine-grained way according to different dimensions (Le and Kroll 2017).

\subsubsection{Duration of International Work Experiences}

We quantify the duration of a CEO's international work experiences as the number of calendar years he or she has spent working abroad. If a CEO had multiple stays abroad over the course of his or her career, we summed the total years of all stays (see also Carpenter et al. 2001; Schmid and Altfeld 2018).

\subsubsection{Timing of International Work Experiences}

To capture the timing of an international work experience of a CEO, for each international work experience, we first measure the time in years between the year in which the respective international work experience ends and the year for which we measure a CEO's total compensation. Second, we add the timing measures of all different international work experiences of the specific CEO; we thus take into account the temporal distance of every single stay abroad a CEO has had.

\subsubsection{Breadth of International Work Experiences}

The breadth of international work experiences refers to the number of international work experiences a CEO has completed throughout his or her career, i.e., how often he or she has worked abroad. We therefore set the breadth of international work experiences equal to the number of total different, distinguishable stays abroad that an individual had before being appointed to the CEO position (see also Takeuchi and Chen 2013; Tesluk and Jacobs 1998).

\subsection{Moderator Variable}

Our moderator variable refers to the individual maturity of a CEO. Consistent with established approaches in upper echelons research, we use demographic characteristics to proxy maturity. In this regard, prior literature allows us to differentiate between a 'general' and a 'professional' perspective on maturity. First, it has 
been argued that achieving 'general' maturity is related to age (Sheldon and Kasser 2001), in that older CEOs have more overall experience, beyond a professional context. Second, in terms of 'professional' maturity, it has been suggested that individuals become more mature the longer their career lasts (Costanza et al. 2012; Hunt and Saul 1975; Morrow and McElroy 1987). The more years have passed since the start of a CEO's professional career, the more improved his or her capability to act responsibly and make decisions (Hersey and Blanchard 1969; Sheldon et al. 2006; Steinberg and Cauffman 1996). We measure age and career length in years, respectively, and add the two variables to form a composite index (Greco et al. 2019; Schlossarek et al. 2019). A factor analysis reveals similar factor loadings for age and career length, which is why we do not weigh the variables in our composite index.

\subsection{Control Variables}

Since a broad variety of factors can affect CEO compensation (for an overview, see, for instance, Finkelstein and Hambrick 1989), we control for these factors in our empirical models.

CEO compensation is affected by firm-level factors. Many studies have suggested that a larger firm size is associated with higher compensation levels (Deckop 1988; Kostiuk 1990; Oesterle et al. 2016; Veliyath 1999). Consistent with prior studies (Carpenter et al. 2001), we operationalize firm size as the total sales (logarithmized) of the firm headed by the respective CEO. Firm performance is another factor that affects CEO compensation (Boschen et al. 2003; Firth et al. 2006; Kish-Gephart and Campbell 2015; Peng et al. 2015); so we control for firm performance by adding an accounting-based and a stock-market-oriented variable. Accounting-based firm performance is measured as the return on equity, i.e., net income divided by shareholders' equity. Stock-based firm performance is operationalized as the percentage change in the stock price over the past year. Prior studies have shown that a firm's risk may be linked to executive compensation, with higher risk leading to pay premiums (Datta and Iskandar-Datta 2014; Gormley et al. 2013; Miller et al. 2002); hence, we add a control variable for firm risk and operationalize it as the beta for the past year, i.e., the responsiveness of the stock price to changes in the overall stock market. Since firm-level variables do not immediately affect the compensation of a CEO, we ensure that there is a time lag of one year between the measurement of firm-level control variables and total compensation (Carpenter et al. 2001).

As compensation levels differ across industries (Porac et al. 1999; Rose and Shepard 1994), we include industry dummies based on industry categories according to SIC codes. Prior literature suggests that compensation can significantly differ between countries (Conyon and Schwalbach 2000; Filatotchev and Allcock 2010; Ramaswamy et al. 2000; Townsend et al. 1990; Tremblay and Chenevert 2005); so we add country dummies indicating the respective country of origin of the firm for which the CEO works.

At the individual level, we include gender as a control variable, because gender differences may be a driver of differences in CEO compensation (Blau and Kahn 2000, 2003; Grund 2015; Kulich et al. 2011). We code male CEOs as '1', whereas female 
CEOs are coded as ' 0 '. We also control whether the CEO under investigation is a foreigner, since prior studies draw a connection between an individual's origin and his or her compensation (Fernandes et al. 2013; Posner 2008). If the CEO was not born in the country in which the headquarters of his or her focal firm is located, we code the case as ' 1 '. In turn, we code the case as ' 0 ' if the CEO has no foreigner status. Moreover, we acknowledge that a CEO's internationalization results not only from his or her international work experience, but also from linkages he or she has to foreign countries; therefore, we take into account his or her involvement on boards in foreign countries (Heijltjes et al. 2003; Schmid and Wurster 2016). Like international work experience, foreign board positions can be considered valuable, and they can have an influence on compensation. We thus add a control variable for the total number of foreign board positions, operationalized as the total number of seats a CEO has on boards abroad.

\subsection{Empirical Approach}

In the same vein as previous studies on top managers' compensation, we apply regression analysis to test our hypotheses (see, for instance, Carpenter et al. 2001; Conyon et al. 2019; Oxelheim and Randøy 2005; Randøy and Nielsen 2002). We assume a linear relationship between the duration, timing and breadth of international work experiences and compensation (Hayes 2017; Mendenhall and Sincich 2011). We cannot identify any major endogeneity issues with regard to reverse causality. While we investigate the influence of past international work experiences on current compensation, we would not expect today's compensation to affect past stays in foreign countries (Hamilton and Nickerson 2003; Imbens and Rubin 2015).

To test hypotheses 1-3, we regress CEO compensation on the duration, timing and breadth of international work experiences. To investigate the indirect influence of maturity on the relationships between different dimensions of international work experiences and compensation, we perform moderated regression analyses (Hayes 2017; Mendenhall and Sincich 2011). For our moderation hypotheses (hypotheses 4a-4c), we assume that maturity positively moderates the linear relationships between the duration, timing and breadth of international work experiences and compensation. Hence, we add maturity as the moderator variable and interaction terms for maturity with duration, timing or breadth of international work experiences, respectively (Hayes 2017; Izenman 2013). To avoid multicollinearity in our regression models, we mean-centre the independent and moderator variables by subtracting the mean value of a variable across the entire sample from the variable's value in each specific case (Aiken and West 1991; Kohler and Kreuter 2012; Zhang and Rajagopalan 2010).

\section{Results}

\subsection{Main Analysis}

Table 1 provides descriptive statistics and correlations for the dependent, independent, moderator and control variables. The variables for duration, timing and 


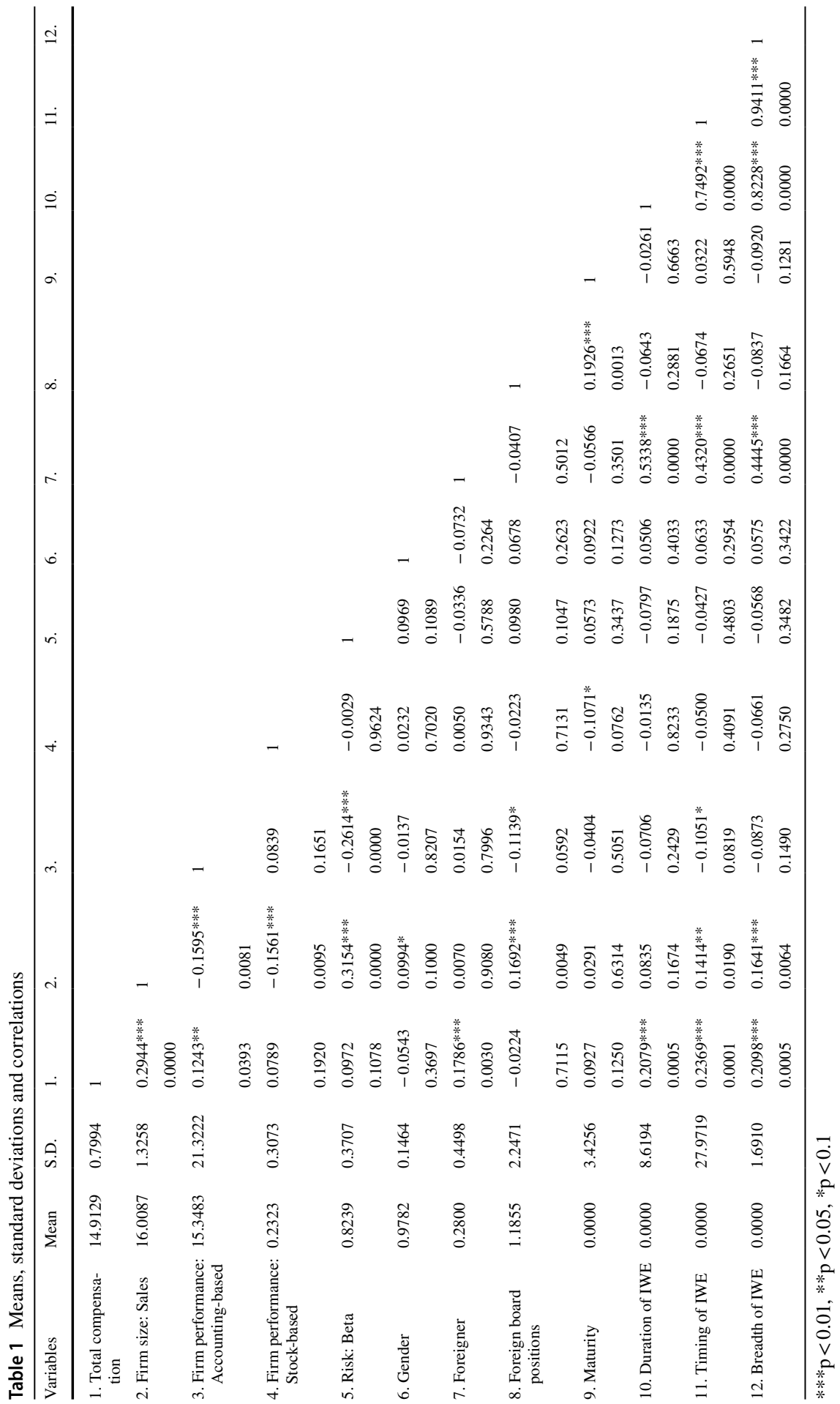


breadth of international work experiences and maturity have a mean value of zero, because they are mean-centered (Aiken and West 1991; Zhang and Rajagopalan 2010). Intuitively, we may believe that maturity is correlated with the duration, timing and breadth of international work experiences. In other words, we may assume that there is a direct, significant relationship between maturity and the duration, timing and breadth of international work experiences (McKnight et al. 2000). However, our data do not support such an assumption. Therefore, it is from not only a theoretical, but also a statistical standpoint that we can justify using maturity as a moderator for the relationships between our dimensions of international work experiences and compensation.

Not surprisingly, we identify highly significant correlation coefficients between all of our independent variables, i.e., duration, timing and breadth of international work experiences. These correlations are also evident when calculating Spearman correlation coefficients for the independent variables (Hauke and Kossowski 2011). To respond to concerns about correlation, we first investigate VIFs. In this regard, we have to create a consolidated model in which we include all independent variables at once, i.e., duration, timing and breadth of international work experiences. While timing and breadth indeed have a VIF close to the common cutoff value of 10 , interestingly, duration shows a VIF of 3.88 only, far below the common cutoff value of 10. According to this analysis, timing and breadth are different from duration, which has so far been the most commonly used construct for international work experience. For the operationalization of international work experience, it therefore appears as if an operationalization with duration cannot fully substitute for also considering timing and breadth. Hence, we conclude that it is warranted to investigate different dimensions of international work experience despite their correlations.

Nonetheless, we refrain from a consolidated model for our main analysis. One reason is that timing and breadth have a tendency towards a high VIF. Another reason is that even when choosing a consolidated model, the analysis of VIFs does not entirely alleviate concerns associated with the multicollinearity of the independent variables. We thus opt for separate models that include only one independent variable, i.e., the duration or the timing or the breadth of international work experiences, respectively.

To ensure the construct validity of our measure for maturity, which includes age and career length, we first calculate Cronbach's alpha (Peterson 1994). The coefficient for maturity lies well above the common cutoff value of 0.7 (Christmann and Van Aelst 2006; Kopalle and Lehmann 1997). Moreover, we calculate several additional measures to assess the validity of our two-item scale, such as Pearson or Spearman-Brown measures, all of which confirm the validity of combining age and career length into a composite measure (Eisinga et al. 2013).

The results for the models employed to test hypotheses 1-3 and moderation hypotheses $4 a-4 c$ are reported in Table 2 . The first column, titled 'Model 1 ', shows the results for the baseline model without any of the independent or moderator variables included. The following three columns add the independent variable for the duration (Model 2), or for the timing (Model 3) or for the breadth (Model 4) of international work experiences. The remaining models test for a moderation effect of maturity and add an interaction term for maturity and 


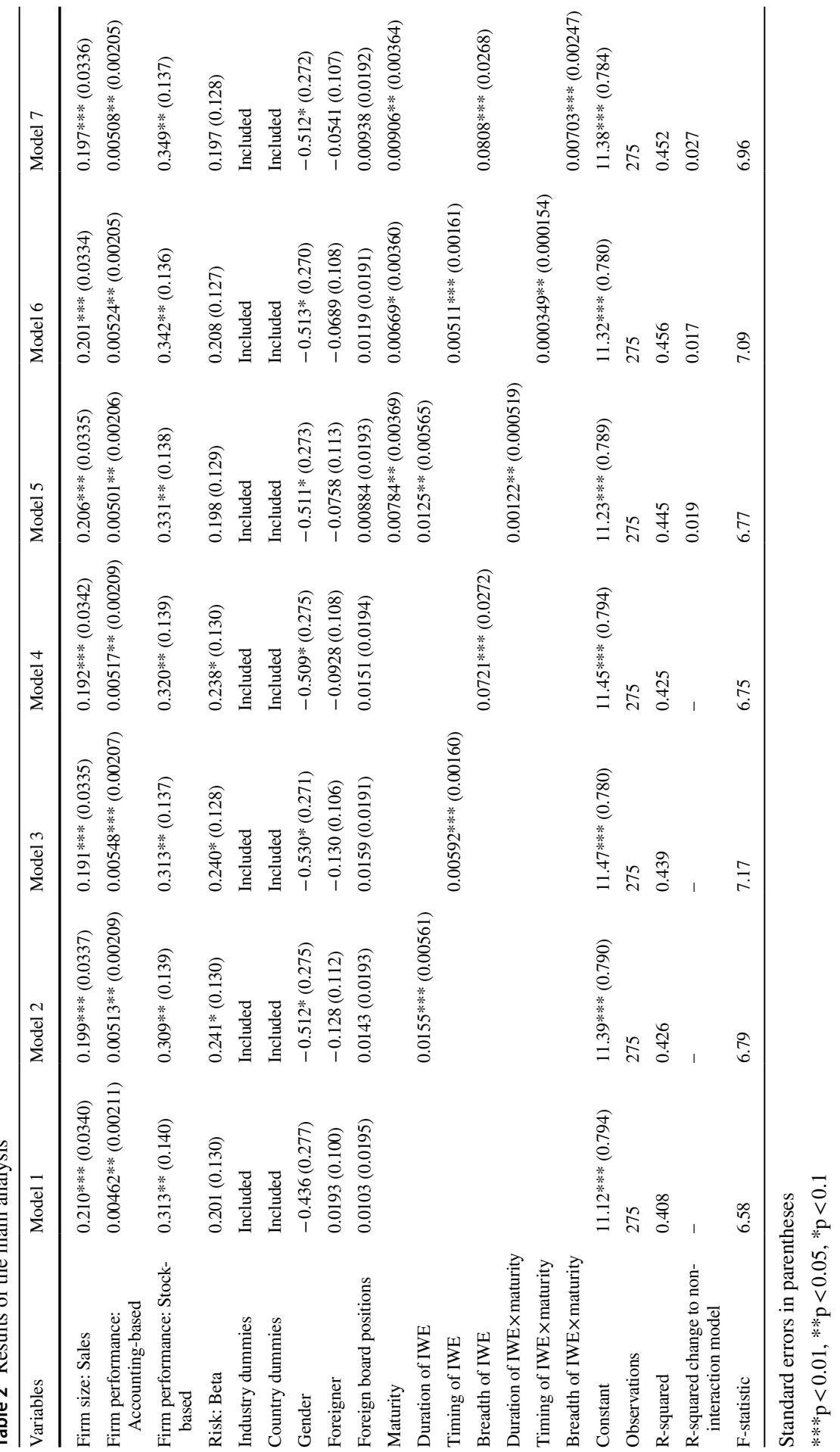


duration (Model 5), timing (Model 6) or breadth (Model 7) of international work experiences. None of our models exhibits severe issues with multicollinearity, as the variance inflation factor for each model lies well below the common cutoff value of 10 (O'Brien 2007). When adding the different independent and moderator variables to the baseline model, the explanatory power of our regression models increases $\left(\mathrm{R}^{2}\right)$, which supports our reasoning that different dimensions of international work experiences and maturity are relevant factors at the individual level that interfere with CEO compensation.

Across all models, firm size appears to influence compensation significantly. Furthermore, other firm-level variables such as accounting performance, stock performance and risk affect a CEO's total compensation. In many models, the industry and country of origin of the firm also impact total compensation. While the aforementioned variables are major drivers of compensation at the firm, industry or country level, we also find broad support for the relevance of individual-level determinants that influence compensation. For instance, according to most models, gender appears to influence total compensation.

Our regression models support two of our three main hypotheses. We can confirm hypotheses 1 and 3, as we identify a significantly positive association between the duration and breadth of international work experiences and CEO compensation in Models 2 and 4. Our results suggest that an increase in the duration of a CEO's international work experiences by one year causes an increase in total compensation of $1.56 \%$ on average. Broader international work experiences also pay off for CEOs, as each additional international work experience yields a total compensation that is $7.48 \%$ higher on average. The result for timing is significant as well-however, it does not display the expected sign (Model 3): With each additional year an international work experience dates back further, the timing variable increases. A high value attributed to the timing variable indicates earlier experiences that, according to our hypothesis 2, we assume to be less favorable for compensation than later experiences. Building on our theoretical assumption, we therefore expect a negative sign for the timing coefficient. However, according to our empirical results, the opposite is the case. Timing has a positive sign, i.e., the higher the temporal distance of a CEO's international work experiences, the higher the compensation level. For each year that an international work experience starts earlier, total compensation increases by $0.59 \%$ on average (all coefficients are significant at the $1 \%$ level).

Moreover, we find evidence in support of our moderation hypotheses $4 \mathrm{a}-4 \mathrm{c}$, as our models display significant interaction terms for maturity and duration (Model 5), maturity and timing (Model 6) as well as maturity and breadth (Model 7) of international work experiences. Therefore, our results confirm that maturity positively moderates the positive relationship between compensation and longer, earlier and broader international work experiences, respectively. Figure 2 visualizes these moderation effects and shows the interaction plots for duration, timing and breadth of international work experiences and maturity. 

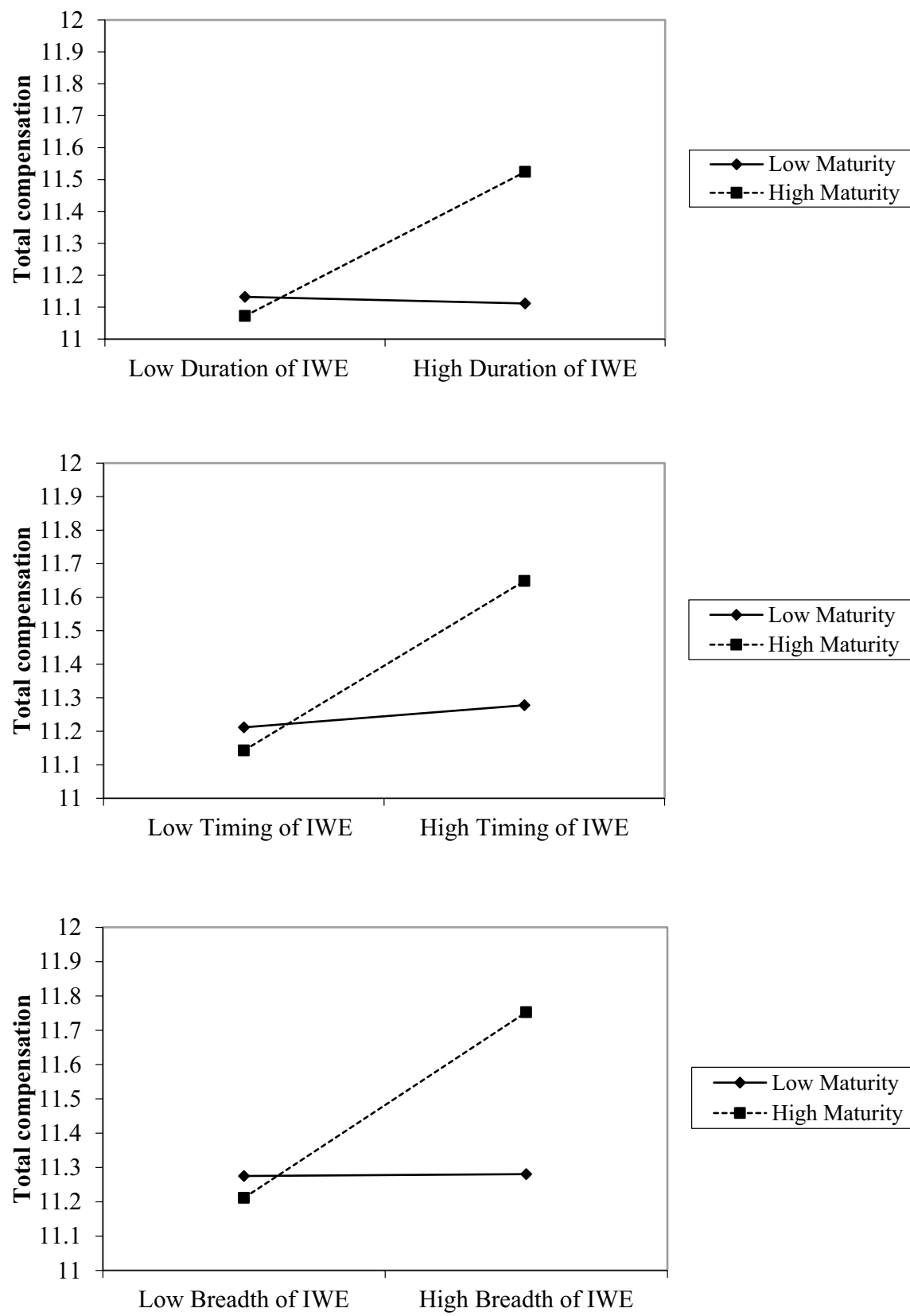

Fig. 2 Interaction plots 


\subsection{Robustness Checks}

We conduct several robustness checks to ensure the validity of our results. ${ }^{1}$

\subsubsection{Combining Duration, Timing and Breadth of International Work Experiences}

We argue in favor of separately analyzing duration, timing and breadth of international work experience (following Le and Kroll 2017; Reiche et al. 2019; Takeuchi and Chen 2013). However, it can also be claimed that the different dimensions should be used to construct composite indices (Greco et al. 2019). Hence, in a first robustness check, we acknowledge that we may not only analyze the different dimensions in isolation (as in the main analysis), but that we can also combine them in different ways, which allows us to analyze their joint effects. In addition, combining the different measures for international work experience also helps address the issue of their high correlations.

The results of a principal component analysis indicate that duration, timing and breadth indeed cluster and can thus be used to construct indices (Abdi and Williams 2010; Bro and Smilde 2014). For our composite indices, we use different linear and non-linear combinations of duration, timing and breadth (Greco et al. 2019; Schlossarek et al. 2019):

- Composite index (a): First, we acknowledge the absolute relevance of each dimension and opt for a simple linear combination of duration, timing and breadth of international work experience.

- Composite index (b): Second, timing may affect the value of duration and breadth of international work experience in relative terms. Therefore, we add duration and breadth of international work experience and weigh the sum of duration and breadth with timing. We also add models in which only duration or breadth are weighed separately by timing.

- Composite index (c): Third, merely accumulating the duration and timing of a CEO's different international work experiences might blur the regression results in favor of those CEOs with multiple, i.e., broader experiences (Hitt et al. 2007; Roth 1995). For instance, CEOs with broad international work experience might tend to have a longer total duration of international work experiences or more stays abroad that date back further. We thus add duration and timing and divide the sum by breadth, in order to depict the average duration and timing of international work experience. Again, we also rerun our analyses with separate measures for average duration and average timing.

Results are reported in Appendix 1 (with a composite index as independent variable as described in (a)), Appendix 2 (composite index as described in (b)) and Appendix 3 (composite index as described in (c)). Our data show a significant effect of the composite index with a linear combination of duration, timing and breadth

\footnotetext{
${ }^{1}$ Results of robustness checks not included in this paper are available from the authors upon request.
} 
(Appendix 1), as well as the composite indices with breadth as a weighting factor (Appendix 3). This confirms our notion that the joint effects of the different dimensions of international work experience likewise matter for compensation. Moderation cases reveal that a moderating influence of maturity is also observable when factoring in the interaction between the different dimensions of international work experience.

\subsubsection{Considering Cultural Distances of International Work Experiences}

Our second robustness check refines international work experience (i.e., our independent variable). The value of international work experiences for a $\mathrm{CEO}$ and his or her firm may be influenced by the country or countries in which a CEO has had his or her stays abroad, i.e., the "foreign cultural context" (Takeuchi and Chen 2013; see also Dane 2010). It has been argued that top managers' international experience in a more close country is different from the one gained in a more distant country (Al Ariss et al. 2012; Le and Kroll 2017; Ramaswami et al. 2016; Shenkar 2001; Sousa and Bradley 2006; Zhang 2013). Consequently, for our second robustness check, we include cultural distances to the countries in which work experiences took place. We rely on Hofstede's data, which is still the established approach in IB literature (Beugelsdijk and Welzel 2018; Beugelsdijk et al. 2017). We hand-collected data for each individual country in which our CEOs had their respective international experiences. Based on these data, we created cultural distance indices with the Hofstede data. As calculating Euclidic distances, such as practiced in the commonly used Kogut and Singh (1988) approach, has been criticized in literature, we opt for an alternative calculation (Ambos and Håkanson 2014; Cuypers et al. 2018). We follow Yeganeh (2014) and use Mahalabonian distances as a basis for calculating our cultural distances. In a next step, our distance measures are applied as a weighting factor for the duration, timing and breadth of each international work experience (Le and Kroll 2017). For every CEO, we then calculate the total duration, timing and breadth weighed by cultural distance.

Results can be found in Table 3 (Models 1-3); moderation cases for maturity are added as well (Models 4-6). The robustness check confirms and adds to the results of our main analysis, so it can be concluded that the cultural distance of the countries in which a CEO has stayed is associated with the value of the respective international work experience. Our results indicate that in line with increasing cultural distance, long, early and widespread international work experiences may become more valuable.

\subsubsection{Differentiating Between Fixed and Variable Compensation}

For a third robustness check, we focus on our dependent variable and rerun our analysis with different operationalizations of compensation. While many authors would argue that individual characteristics affect total compensation (Carpenter et al. 2001; Conyon et al. 2019), some studies suggest that these individual-level factors predominantly influence fixed compensation components (McKnight and Tomkins 2004; Murphy 2013; Peng et al. 2015). According to these studies, variable compensation 


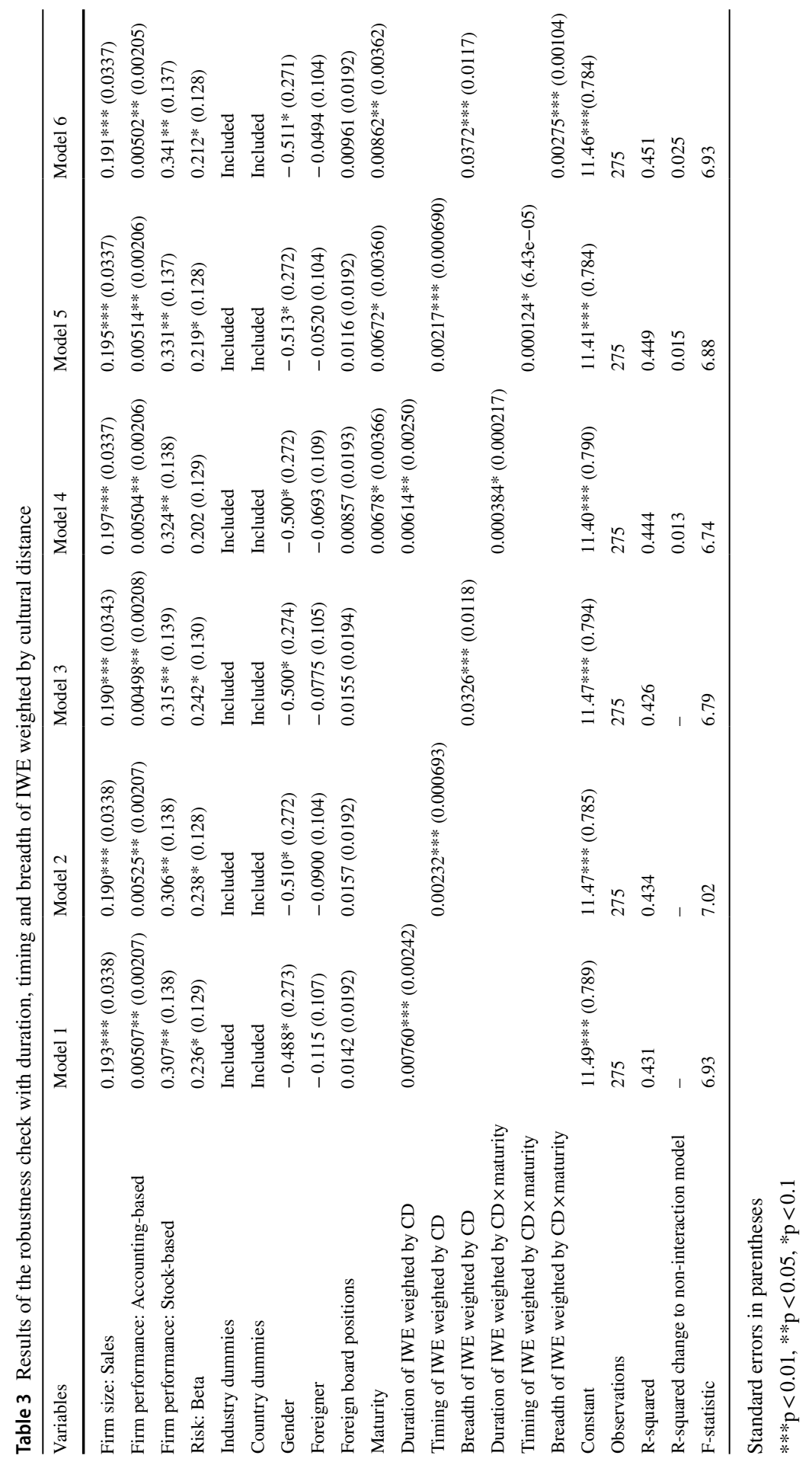


components might primarily depend on other factors, such as firm performance (Coughlan and Schmidt 1985; Mehran 1995; Smirnova and Zavertiaeva 2017).

In order to account for possible differences in the influence of international work experiences on different compensation components, we performed additional analyses with either salary (as the most important component of fixed compensation) or variable compensation as the dependent variable. Taking a CEO's salary as the dependent variable, we are able to confirm that the different dimensions of international work experiences and maturity as a moderator matter for fixed compensation (see Table 4). In another robustness check, we repeated the regressions with variable compensation as the dependent variable. This robustness check yields significantly positive results for the relationships between the duration, timing and breadth of international work experiences and variable compensation, albeit a moderating effect of maturity cannot be identified (see Table 5). Hence, with our data, we cannot confirm that international work experience affects salary more strongly than variable compensation components. Indeed, the effect sizes of our independent variables for international work experience are larger in the models that use variable compensation as a dependent variable.

\subsection{Supplementary Analyses}

We carried out several supplementary analyses to complement our main analyses.

\subsubsection{Testing for an Inverted U-Shaped Relationship}

First, based on our theoretical framework, we assume a linear relationship between the duration, timing and breadth of international work experiences and compensation. However, some authors have suggested that the relationship between international experience and compensation (and other individual-level outcomes such as time to the top) may be described better by an inverted U-shape (Georgakakis et al. 2016; Schmid and Altfeld 2018). The reasoning behind this suggestion refers not only to human capital theory, but also to social capital theory. On the one hand, international experiences are expected to increase human capital, as they help to improve an individual's skills, knowledge and competencies, which eventually translate into higher compensation levels (Carpenter et al. 2001; Fitz-Enz 2000). On the other hand, international experiences are expected to weaken social ties and thus decrease social capital in the focal firm or home country, which would be to the detriment of compensation (Athanassiou and Roth 2006; Blyler and Coff 2003; Kwon and Adler 2014). While international experiences increase individuals' compensation levels initially, after a certain point, they may be associated with decreasing compensation levels, because negative social capital effects outweigh positive human capital effects (Schmid and Altfeld 2018).

To test empirically if this line of argument holds, we check for potential inverted U-shaped relationships within our models. We rerun our regression models by adding a squared term for the duration, timing and breadth of international work experiences and interaction terms operationalized with squared international work experiences to the 


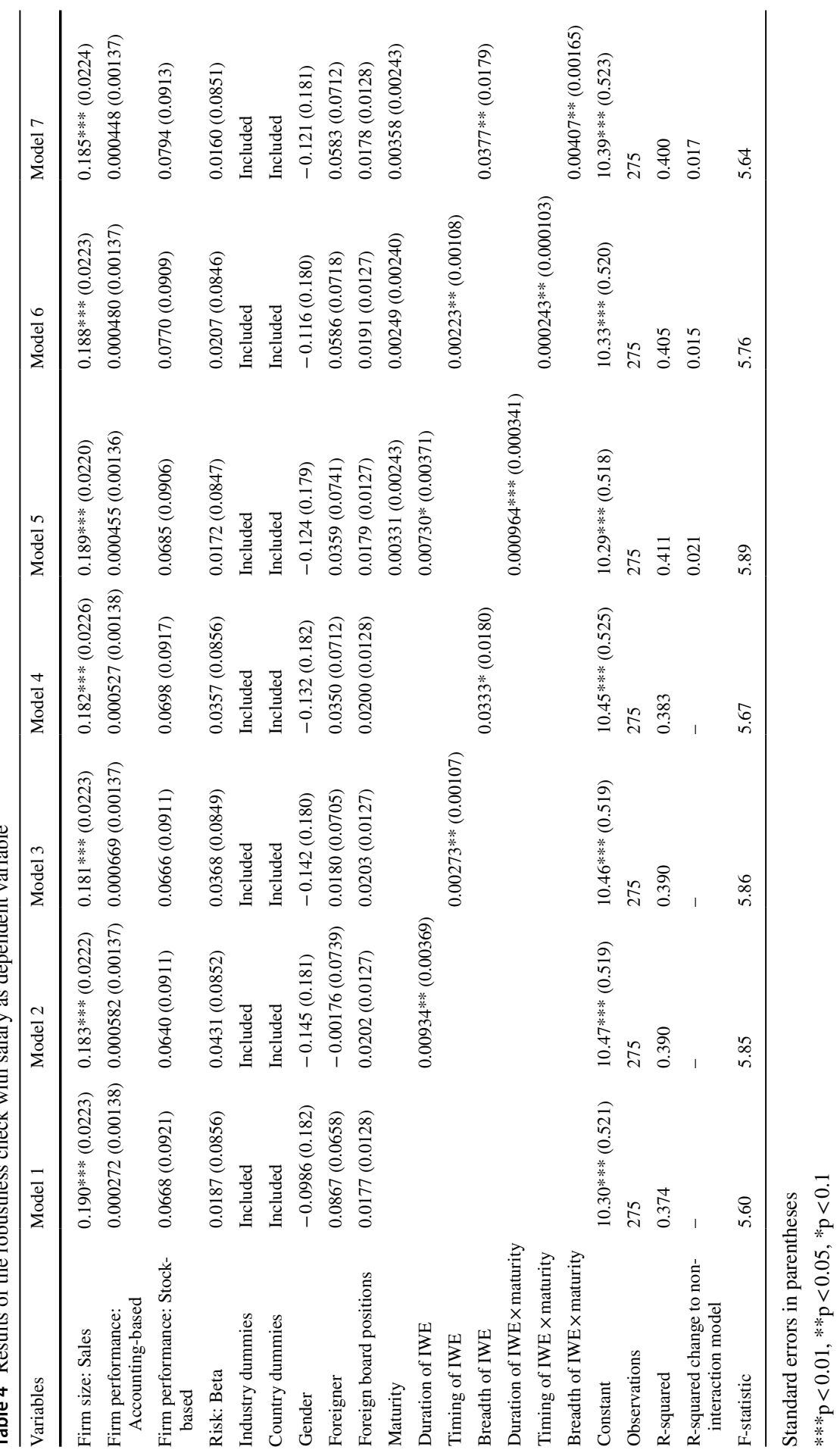


moderation models (Haans et al. 2016; Lind and Mehlum 2010; Sturman 2003). However, with regard to the empirical results, we find no indication of an inverted $\mathrm{U}$-shaped relationship between any of our independent variables and compensation (Appendix 4). Consequently, our data do not support the argument that very long or manifold international work experiences could be 'too much' (Georgakakis et al. 2016) or that international work experiences from the very early phases of a career could be 'too early' (and hence could have harmful effects on compensation).

\subsubsection{Incorporating International Education Experience}

Furthermore, it has to be acknowledged that international experience may be obtained not only while working abroad, but also while studying in a foreign country (Carpenter et al. 2003). In their conceptual article, Takeuchi and Chen (2013, p. 251) suggest that considering international education experience (IEE) "can help provide a more complete picture of international experiences". As the findings of our main analysis revealed that earlier international work experience shapes compensation, we argue that international education experience may also matter for pay. Just like international work experience, international education experience may increase human capital, and it can be a valuable resource for firms and deliver returns for individuals (Miller et al. 2015). Hence, in another supplementary analysis, we focus on international education experiences and their effect on compensation. For our analysis, we consider all international education experiences a CEO has completed after achieving a high school-level education (such as studies for Bachelor's or Master's degrees). Regression analyses for our supplementary analysis show no significant relationship between the duration of international education experiences and compensation. However, we find evidence for a significant relationship between the timing and breadth of international education experiences and compensation, such that earlier and manifold international education experiences are particularly valuable. Again, the results suggest that considering multiple dimensions of a construct can be fruitful, as the most common measure of international experience - duration - does not yield significant results. No moderating role of maturity can be identified (see Appendix 5).

In a final step, we use both international education experiences and international work experiences to construct our independent variables (Conyon et al. 2019; Schmid and Wurster 2016). We obtain results mostly in accordance with the main analysis (see Appendix 6), and our results suggest that the duration, timing and breadth of international work and education experiences positively affect a CEO's compensation. Longer, earlier and more numerous experiences also increase compensation. Maturity positively moderates the relationships for duration and breadth.

\section{Discussion}

Our study shows that next to the duration of a CEO's international work experiences, the timing and breadth of international work experiences also have an impact on remuneration. Furthermore, we reveal that the relationships between different dimensions of international work (and international education) experience are moderated 


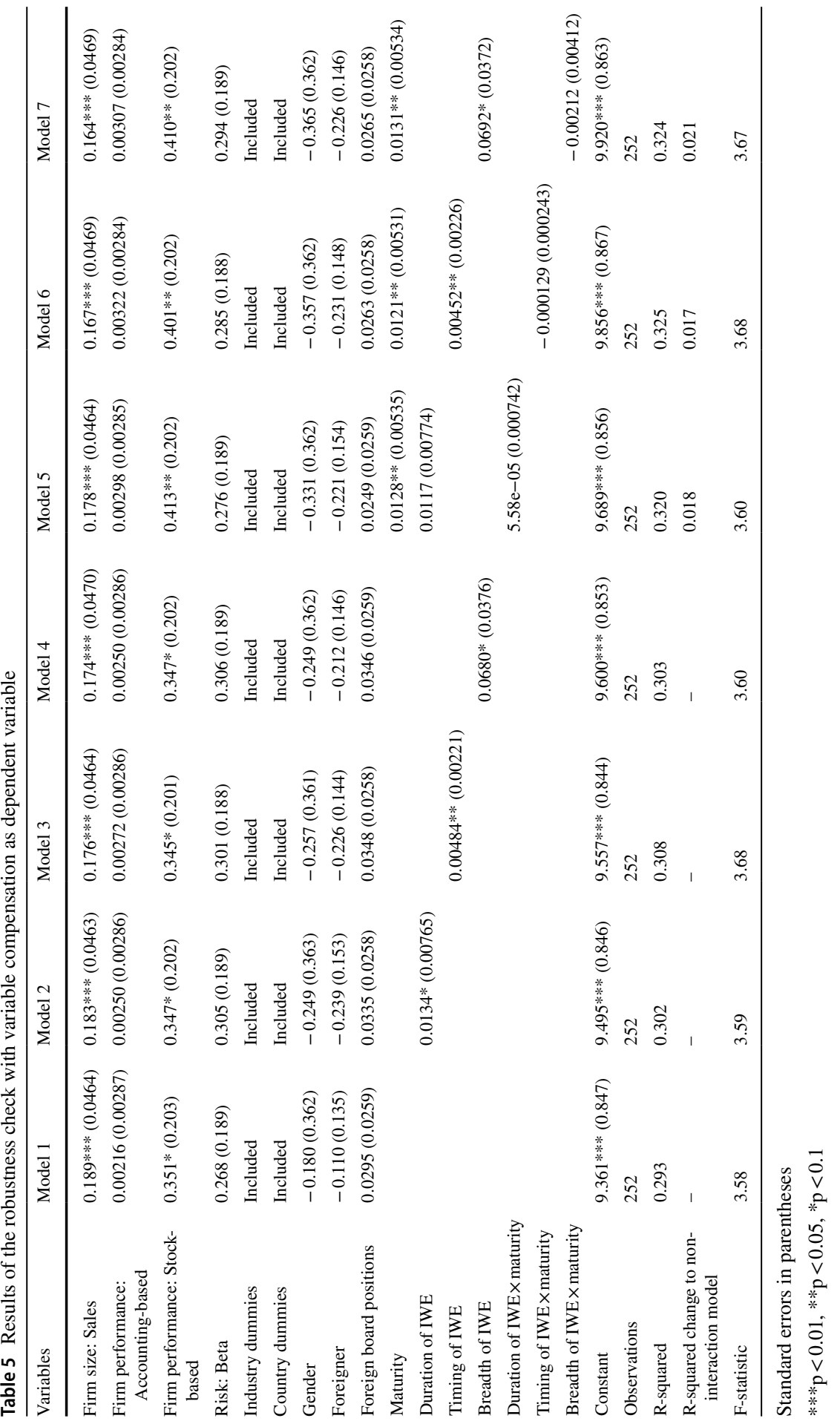


by a CEO's maturity. While we provide empirical evidence that the timing of international work experience is relevant, it does not influence pay in the expected way: We assumed that especially later experiences would pay off for CEOs, as they deliver human capital specific to the tasks of a CEO, but our empirical analysis shows that earlier experiences are particularly rewarding in terms of compensation.

Our results on timing are contrary to our original hypothesis. This should not suggest that late experiences are invaluable but that CEOs may benefit in particular from the general-purpose human capital also associated with early experiences. Some authors stress that early international work experiences are relevant, due to their formative character and their lasting impact on leadership skills and competencies (Buchanan 1974; Takeuchi et al. 2005). In this regard, generalist CEOs can benefit from their overall lifetime experience-also in terms of compensation (Custódio et al. 2013; Li and Patel 2019). Consequently, even though the task-specific human capital obtained in later stays abroad is important for CEOs, it appears as if generalpurpose human capital collected with the help of early international work experiences has a stronger influence on compensation.

In this context, cognitive approaches may help us to explain the importance of early experiences and the general-purpose human capital associated with them (Khanna et al. 2014). Cognition generally refers to mental processing (Eggers and Kaplan 2009; Kitchner 1983) and describes how an individual "uses, changes, enacts, recalls, stores, senses, and transforms knowledge in a dynamic, recursive manner" (Brymer et al. 2011, p. 121). It interferes with memory and affects skills, knowledge and competencies through learning (Tsoukas 1996; Weick 1995), while learning processes can improve the utilization of skills, knowledge and competencies (Kluger and DeNisi 1996; Schmidt and Hunter 2004). In a recent study on international experience, Maddux et al. (2020) argue that stays abroad affect "intrapersonal cognition". In line with Maddux et al. (2020), we may conclude that earlier international work experiences are subject to enhanced mental processing compared to those international work experiences that take place later (Hitt et al. 2001; Zucchella et al. 2007). Over the course of time, formative, early international work experiences are recalled, used and memorized several times (Brymer et al. 2011) and therefore they become internalized. Consequently, learning shapes the realization and value of human capital derived from these early experiences (Brymer et al. 2011; Herrmann and Datta 2006), and it also increases the value of international work experiences and the effect on compensation.

Differentiating between different dimensions of experience allows us to shed light on the influence of international education experience on compensation. While we do not identify a significant effect of the established duration construct, our results show a significant effect of the timing and breadth of international education experiences on CEOs' compensation. When interpreting these results, we can stress that international education experiences enhance individuals' human capital, for instance in terms of foreign language competencies or a general sense of cross-cultural awareness, but they might also serve as an entry ticket to international jobs at a quite high entry level (Kitsantas 2004; Wiers-Jenssen 2008; Williams 2005). Despite not necessarily delivering the task-specific human capital required for the CEO position, they nonetheless come with valuable general-purpose human capital for which firms compensate (Custódio et al. 2013; Gibbons and Waldman 2004), especially in the case of broad international 
education experiences. Consistent with our argumentation on cognition and the mental processing of (early) experiences, we conclude that international education experiences should be particularly valuable, as they date back even further than international work experiences and can thus be internalized even better (Brymer et al. 2011).

Our results, however, do not indicate solely that international experience affects total compensation. Disaggregating total compensation shows that international experiences influence both the salary and variable compensation components. With variable compensation components as a dependent variable, effect sizes are even larger than for fixed compensation components. These results suggest that demographic characteristics, such as international work experiences, can also be reflected in performance-based compensation components (Aguinis et al. 2018). In this regard, CEOs with longer, earlier and broader international experiences may have a better and more powerful bargaining position when negotiating performance-based pay in the first place. In addition, we expect that skills, knowledge and competencies obtained abroad are directly linked to a CEO's ability to perform well. Accordingly, firms can expect CEOs with favorable demographic characteristics, such as international work experience, to have a greater positive impact on performance, which in turn is reflected in higher performance-based pay and, thus, also in total compensation.

\section{Contributions}

Through our study, we answer calls for an improved understanding of CEOs' demographic characteristics and their impact on respective outcomes, such as compensation (see, for instance, Hambrick and Quigley 2014; Reiche et al. 2019; Takeuchi and Chen 2013). In this regard, we address recent calls in IB literature; for instance, Takeuchi and Chen (2013, pp. 280-281) claimed that research would benefit from "a more fine-grained conceptualization of prior international experience", suggesting that "it is necessary to stress the multidimensional nature of international experience", such as by considering the "timing" and "quantity" of experiences. We show that one-dimensional approaches might only provide limited insights into how demographic characteristics translate into specific outcomes (see also Reiche et al. 2019; Takeuchi et al. 2006). With maturity as a contingency factor, we answer calls in upper echelons literature demanding moderated lenses for studying top managers' characteristics and outcomes such as compensation (Abatecola and Cristofaro 2018).

We make theoretical, empirical, as well as practical contributions. Through our theoretical reasoning, we are able to provide a diligent explanation of the mechanism via which international experience translates into compensation. Indeed, prior literature has already stressed that international experience contributes to human capital, which is valuable for firms (Carpenter et al. 2001; Schmid and Altfeld 2018). However, we argue that existing studies insufficiently explain how international experience actually allows CEOs to obtain higher remuneration. In this regard, we extend existing theory on the international experience-compensation nexus: MNCs can 'hire' CEOs with international work experience externally or 'retain' them internally, which puts CEOs with more extensive experience abroad-and hence with more human capital-in a more powerful position. This in turn improves their bargaining position, as 
they exercise power over the compensation-setting process and realize higher pay. By combining human capital approaches with arguments from both resource dependence theory and the resource-based view of the firm, we can show why international experience is a valuable resource translating into compensation. Additionally, using the distinction between general-purpose and task-specific human capital and referring to cognitive approaches, we are able to explain theoretically how different dimensions of international work experience may translate into compensation-which to date has not been sufficiently emphasized by prior literature (Carpenter et al. 2001; Schmid and Altfeld 2018; Schmid et al. 2018). Moreover, drawing on literature that theorizes about maturity, we introduce a novel contingency factor. We argue why maturity positively influences the relationship between international work experience and compensation. This is in contrast to prior literature, which has often pointed towards the downsides of maturity in the context of human capital (Simpson et al. 2002).

Our empirical results allow for novel insights into the value of experience (abroad). Some prior studies have found empirical evidence that international experience is valuable in general (Conyon et al. 2019). In our study, we demonstrate that it is not only the duration, but also the timing and breadth of international experience which are paid for by firms. While existing studies have stressed that late experience in management positions affects outcomes such as compensation (Carpenter et al. 2001; Schulz et al. 2013), we empirically show that particularly early experience in foreign countries is rewarded. Via our supplementary analysis, we also provide evidence that international experience during the early stages of life, such as education, can influence executive remuneration. Furthermore, we find empirical support for the contingent influence of maturity. Hence, an individual's entire set of experiences, including those in the early phases (education, early career), can magnify the positive role that stays abroad have for compensation. Accordingly, we show that next to task-specific human capital, general purpose-human capital matters - even for a 'late career outcome' like CEO compensation (Custódio et al. 2013; Datta and Iskandar-Datta 2014; Li and Patel 2019; Rickley 2019). We thus believe that the relevance of early and general experience may have been underestimated in the past. These experiences are valuable, in that they already put an individual on higher career and compensation levels in the early stages of a career, helping him or her to also progress during subsequent years. Finally, our empirical results show that an internationally seasoned CEO can expect higher variable compensation, thus not confirming the notion that demographic characteristics predominantly affect fixed compensation. This resonates with and adds further arguments to the results of recent studies that place emphasis on variable components in CEO compensation (Aguinis et al. 2018; Schmid and Wurster 2016).

Executive compensation continues to be a relevant topic for firms and stakeholders involved in setting compensation (Arnold and Grasser 2018; Clifford and Lindsey 2016; Gomez-Mejia et al. 1987; Mehran 1995; Perry and Zenner 2000; Tosi and Gomez-Mejia 1994; Tosi et al. 2000). Hence, our study, in addition to its academic contribution, also offers insights for managerial practice. First, our empirical results imply that CEOs with longer, earlier and broader international work experiences are to a certain extent more 'expensive' than their counterparts with a less extensive international career, and a high degree of maturity further increases the price of a CEO's international work experience. Therefore, compensation committees 
within MNCs or compensation consultants providing advice to MNCs (Anderson and Bizjak 2003; Cadman et al. 2010; Hermanson et al. 2012; Murphy and Sandino 2010) should consider that mature CEOs with longer, earlier and broader track records of international experience require higher pay. However, firms may still be willing to pay for internationally seasoned individuals in the CEO position, because their skills, knowledge and competencies are crucial for top management positions in MNCs (Falato et al. 2015). Our results therefore raise awareness of the notion that firms operate in an area of tension between avoiding excessive compensation and properly paying CEOs for valuable characteristics. Second, individuals pursuing an international career and aiming to reach upper echelons (or the CEO position in particular) have to take proper care of their career investments (Inkson and Arthur 2001). In this regard, they have to evaluate whether staying abroad contributes to their aspired career. Previous research has shown that extensive international work experience can also have detrimental effects, such as slowing down the process of reaching an MNC's upper echelons (Hamori and Koyuncu 2011; Schmid and Wurster 2017). However, for CEO compensation, we cannot claim that there can be either 'too much' international work experience, or that international work experience can start 'too early' or become 'too broad'. Although our results suggest a rather positive outlook on the outcomes of international experience, prior research has shown that there can indeed be too much international experience, depending on the position an individual occupies (see, for instance, Schmid and Altfeld 2018 for CFOs and their compensation). While our results therefore confirm that international work experience is a desirable characteristic, they still have to be evaluated in the light of their career stage, current position and the final position to be reached before generalizing what empirically holds true for CEOs.

\section{Limitations}

Limitations of our study highlight promising avenues for future research. Some limitations are related to our sample and our variables. We use a sample of CEOs from the largest firms in Europe, predominantly originating from countries such as France, Germany, Italy, Spain and the United Kingdom. Although we believe it is worthwhile studying the European context, the results obtained in this study only refer to how various dimensions of international work experience and maturity are perceived and valued in Europe (for a discussion of the European context, see also Bruce et al. 2005). In order to generalize our results to other regions and institutional contexts, it would therefore be worthwhile conducting analyses similar to ours but for other parts of the world, e.g., for the Asian continent (for analyses of compensation in an Asian context, see, for instance, Firth et al. 2006; Kato and Long 2006).

For CEOs of large MNCs, it is difficult to obtain direct assessments of their skills, knowledge or competencies of any kind, including those obtained abroad (see also Frydman and Jenter 2010; Harris and Helfat 1997). We acknowledge that assessments, e.g., of the 360-degree type, can help to capture skills, knowledge and competencies of individuals (Chen and Naquin 2006; Gaugler et al. 1987; Hagan et al. 2006; Klimoski and Brickner 1987). However, assessment center data are usually 
more readily available and easily collectible for other employees, such as expatriates in the early or mid-stages of their career-compared to those who have reached the top, i.e., CEOs (Lievens et al. 2003; Mendenhall and Stahl 2000). Analyzing blog posts or other social media activity to assess skills, knowledge and competencies, for instance, with the help of algorithms or trained raters, is possible, yet likewise difficult (Benson et al. 2014; Hitt et al. 2015; Nakara et al. 2012). Most CEOs in our sample are either not (permanently) present or do not disclose much information about themselves on blogs or other social media. In other cases, information about CEOs posted on blogs or other social media is rather a result of firms' communication efforts, and hence does not necessarily reflect the actual skills, knowledge or competencies of CEOs. Due to difficulties in obtaining quantitative assessments, qualitative approaches, such as interviews with CEOs or board directors, might thus further illuminate the skills, knowledge and competencies gathered through international experience. In this regard, future research might also focus on differences in human capital gained throughout self-initiated or assigned stays abroad, as suggested by career and expatriation/repatriation literature (Biemann and Andresen 2010; Cerdin and Pargneux 2010; Jokinen et al. 2008).

Furthermore, despite explaining the relationship between CEOs' international work experience and compensation, we are not able to depict in empirical terms how exactly compensation committees or compensation consultants take into account stays abroad (Anderson and Bizjak 2003; Faulkender et al. 2010; Hermanson et al. 2012). As it might be very challenging or even impossible to grasp the CEO compensation setting process or compensation negotiations in full detail, in particular with a quantitative approach, we suggest qualitative or mixed-methods approaches, in order to gain additional insights into the processes that actually 'translate' international work experience into compensation.

Finally, it has to be noted that we only consider individuals in our study who have been highly successful in their careers and who ascended to the CEO position in large MNCs. Accordingly, we did not analyze managers (or other employees) who reached a "plateau" in their career without advancing any further (see also Veiga 1981). The impact of several dimensions of international work experience on compensation (and the moderating role of maturity) that we study with a sample of CEOs is specific to CEOs (and does not necessarily apply to individuals with other career paths). We acknowledge that international experience may have other effects on compensation in studies that focus on other types of managers (or employees), such as, for example, expatriates in early or mid-career stages. Therefore, future studies may investigate the effect that duration, timing and breadth of international work experience have on the career success of many other individuals in an organizational context in general or in the MNC context in particular.

\section{Conclusion}

CEO compensation remains a topic of high interest, both in academia and in managerial practice (see, for instance, Brockman et al. 2016; Le et al. 2013; Van Essen et al. 2015). When it comes to pay, executives in the CEO position considerably surpass 
their colleagues on the board (Career Chron 2016; Trend 2017). Especially for CEOs in MNCs, international work experience appears to be a relevant characteristic. However, can CEOs with international work experience expect higher compensation? Through our study, we advance knowledge about the direct association between international work experience and compensation, providing evidence that the duration, timing and breadth of international work experiences affect CEO pay. Furthermore, we examine the role of maturity as a contingency factor. Our data show that a CEO's maturity positively moderates the relationships between the duration, timing and breadth of international work experiences and their compensation. We argue in favor of a differentiated approach towards analyzing demographic characteristics of individual CEOs, taking into account several dimensions as well as moderating factors. Such an approach improves our understanding as to why CEOs with international work experience are more expensive. Our research adds to the ongoing debate concerning whether international work experiences are associated with career success (Shaffer et al. 2012), with compensation often being considered one of the most important objective measures of career success (Judge et al. 1995; Wiese et al. 2002).

\section{Appendix 1: Results of the Robustness Check with a Composite Index Comprising a Linear Combination of Duration, Timing and Breadth of IWE}

\begin{tabular}{lll}
\hline Variables & Model 1 & Model 2 \\
\hline Firm size: Sales & $0.191^{* * *}(0.0335)$ & $0.201^{* * *}(0.0334)$ \\
Firm performance: Accounting-based & $0.00549^{* * *}(0.00207)$ & $0.00525^{* *}(0.00205)$ \\
Firm performance: Stock-based & $0.312^{* *}(0.137)$ & $0.339^{* *}(0.136)$ \\
Risk: Beta & $0.246^{*}(0.128)$ & $0.210^{*}(0.127)$ \\
Industry dummies & Included & Included \\
Country dummies & Included & Included \\
Gender & $-0.538^{* *}(0.272)$ & $-0.519^{*}(0.270)$ \\
Foreigner & $-0.150(0.108)$ & $-0.0859(0.109)$ \\
Foreign board positions & $0.0162(0.0191)$ & $0.0119(0.0191)$ \\
Maturity & & $0.00706^{*}(0.00360)$ \\
Duration + timing + breadth & $0.00466^{* * *}(0.00127)$ & $0.00405^{* * *}(0.00127)$ \\
(Duration + timing + breadth $) \times$ maturity & & $0.000290^{* *}(0.000118)$ \\
Constant & $11.50^{* * *}(0.781)$ & $11.32^{* * *}(0.780)$ \\
Observations & 275 & 275 \\
R-squared & 0.439 & 0.458 \\
R-squared change to non-interaction model & - & 0.019 \\
F-statistic & 7.16 & 7.14 \\
\hline
\end{tabular}

Standard errors in parentheses

$* * * \mathrm{p}<0.01, * * \mathrm{p}<0.05, * \mathrm{p}<0.1$ 


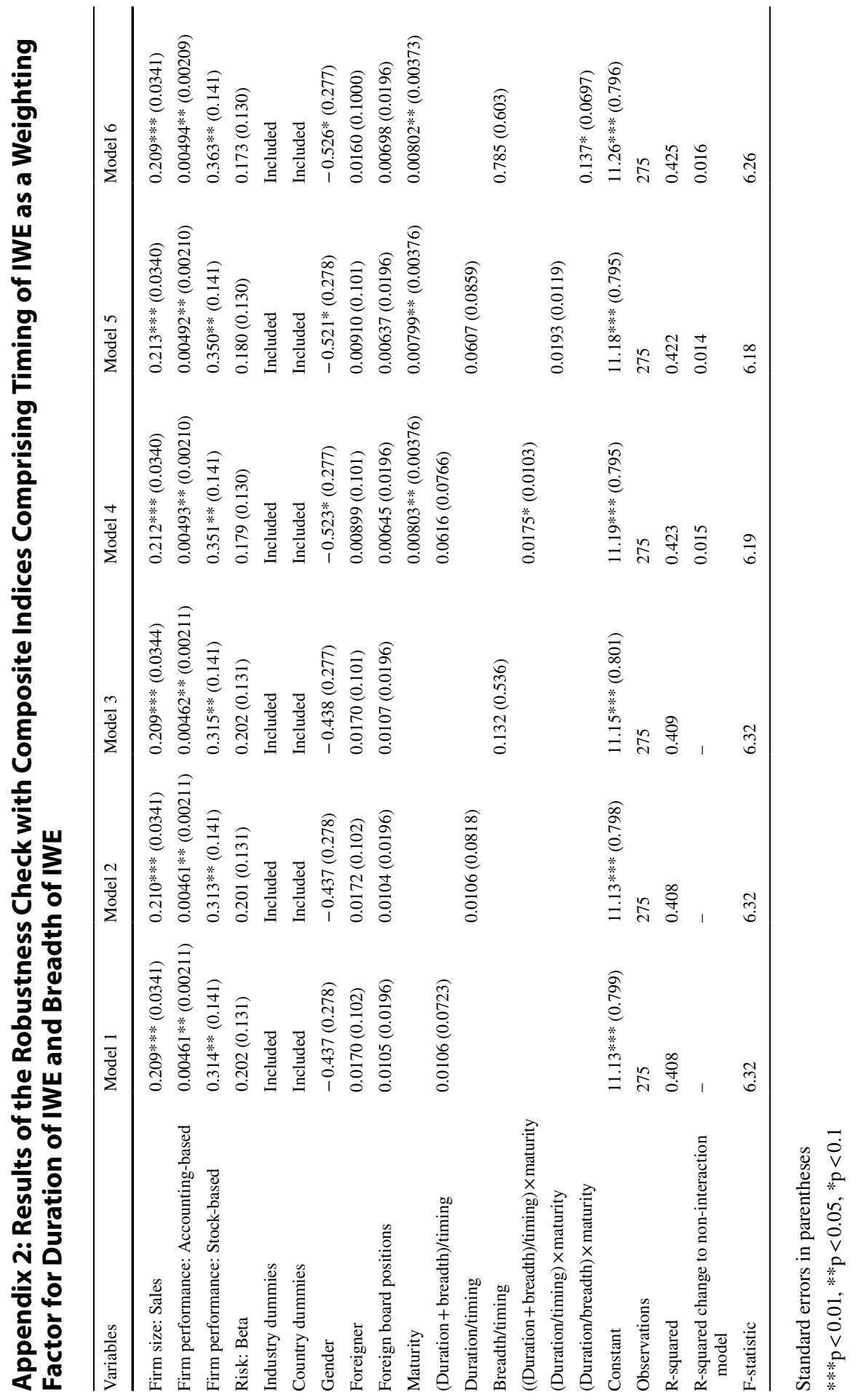




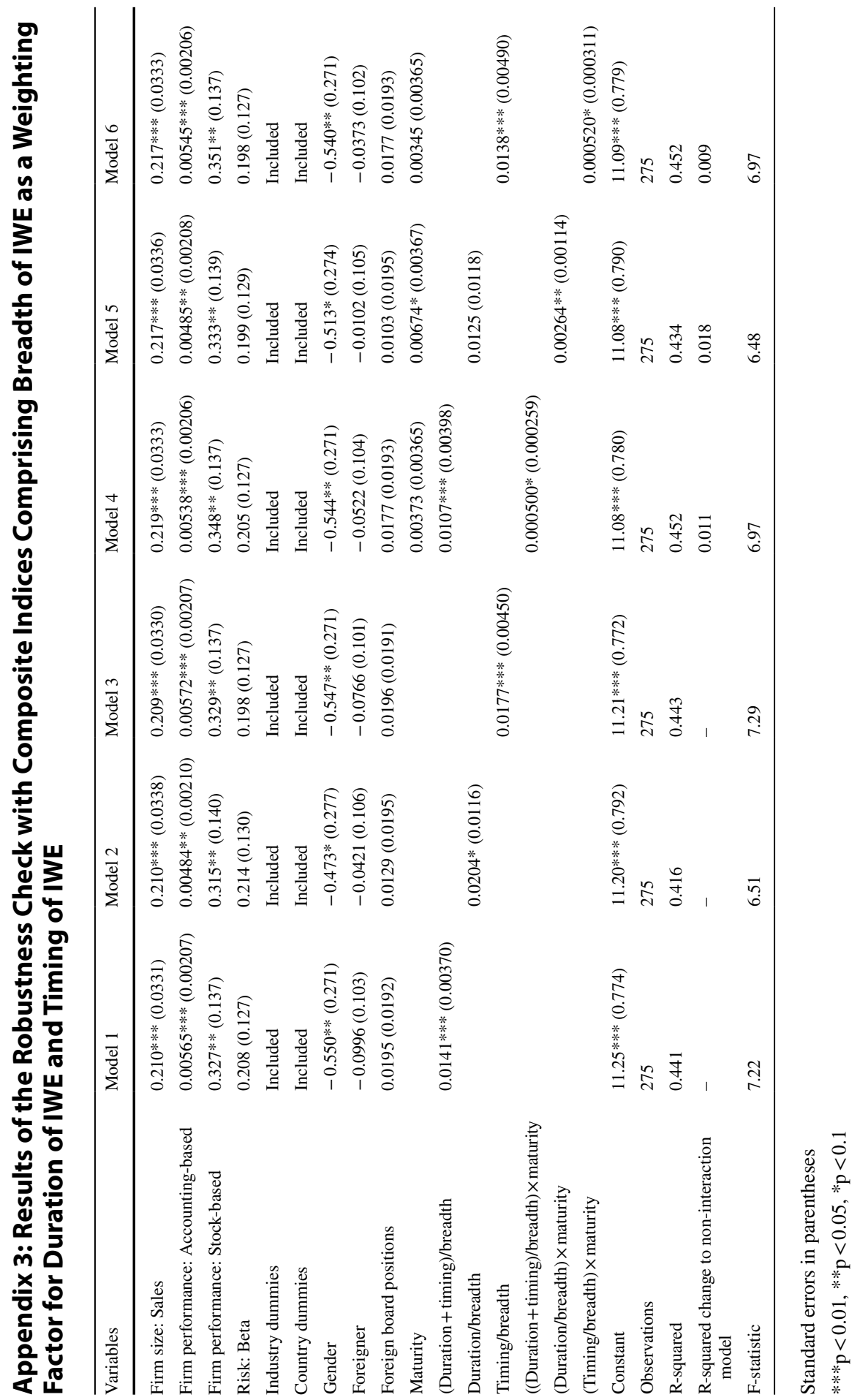




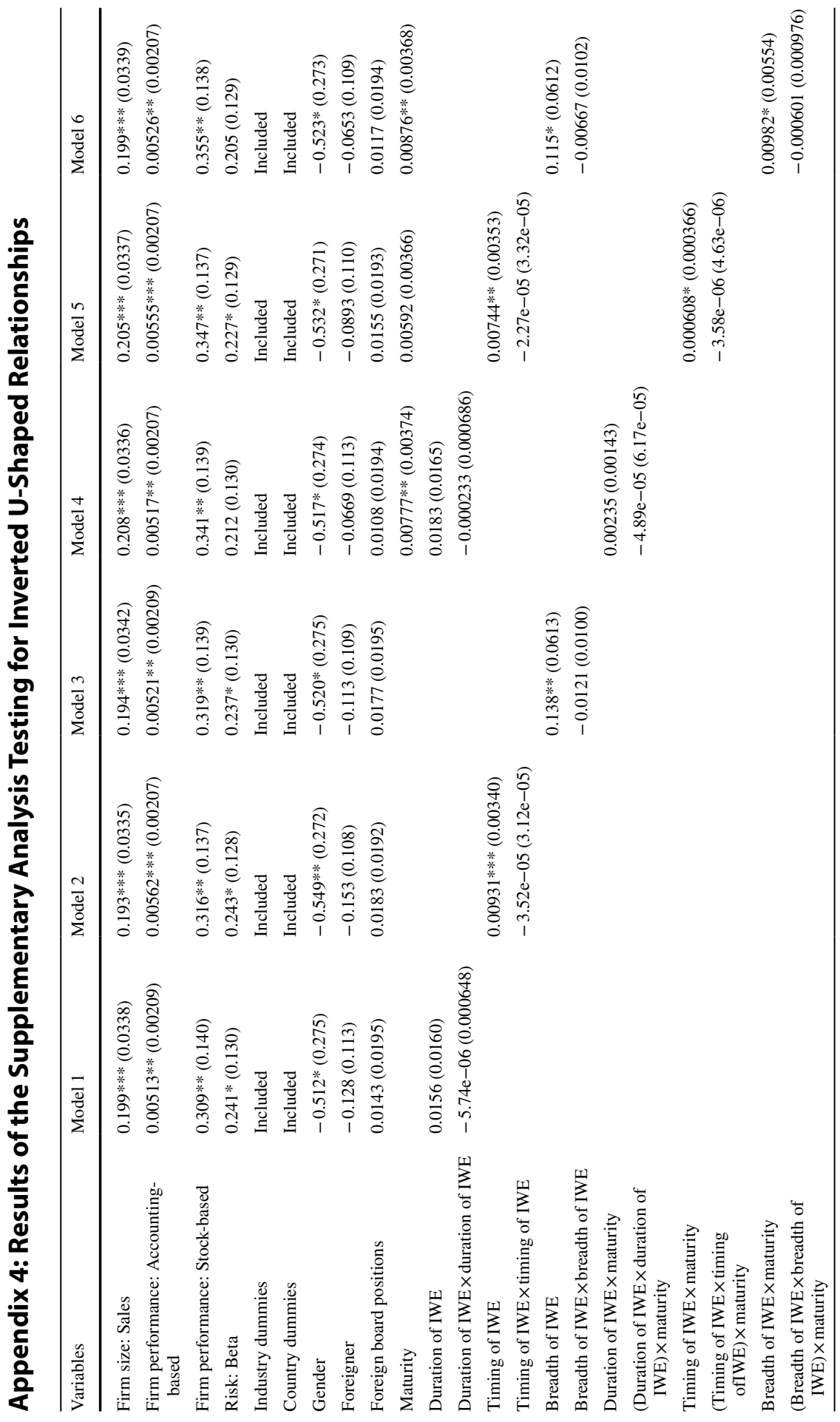




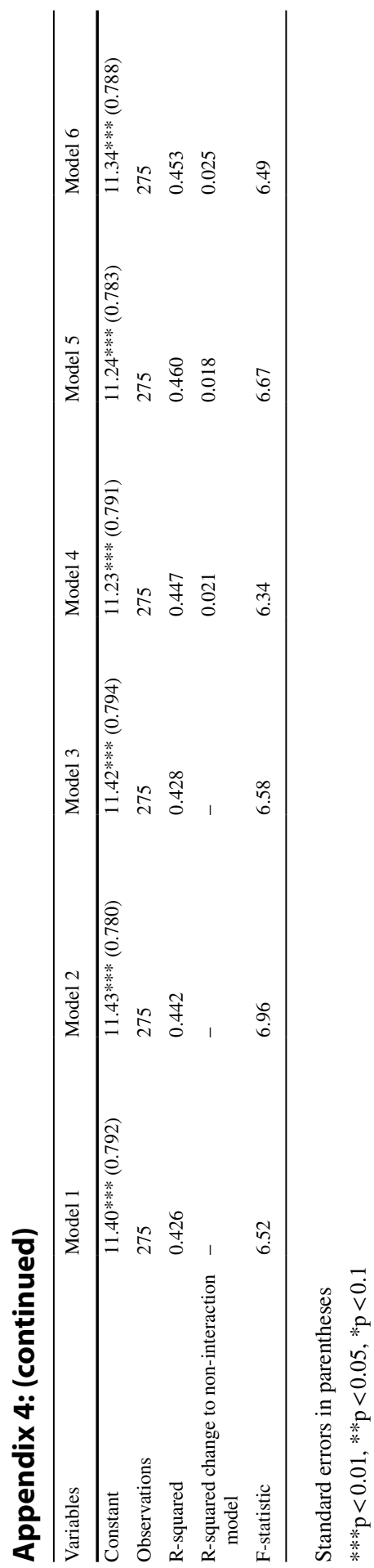

글 Springer 


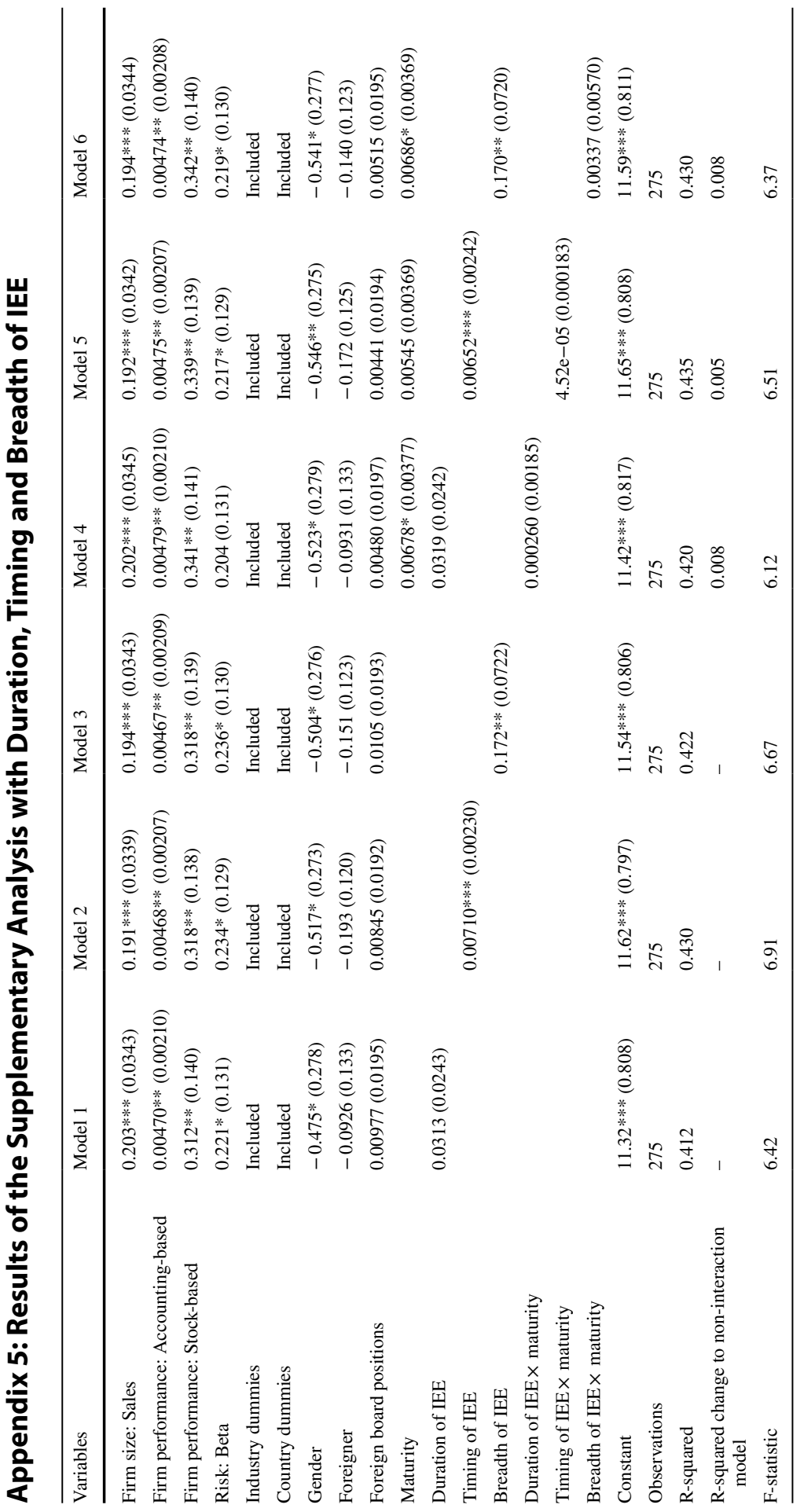

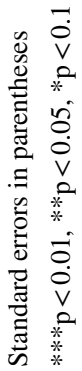




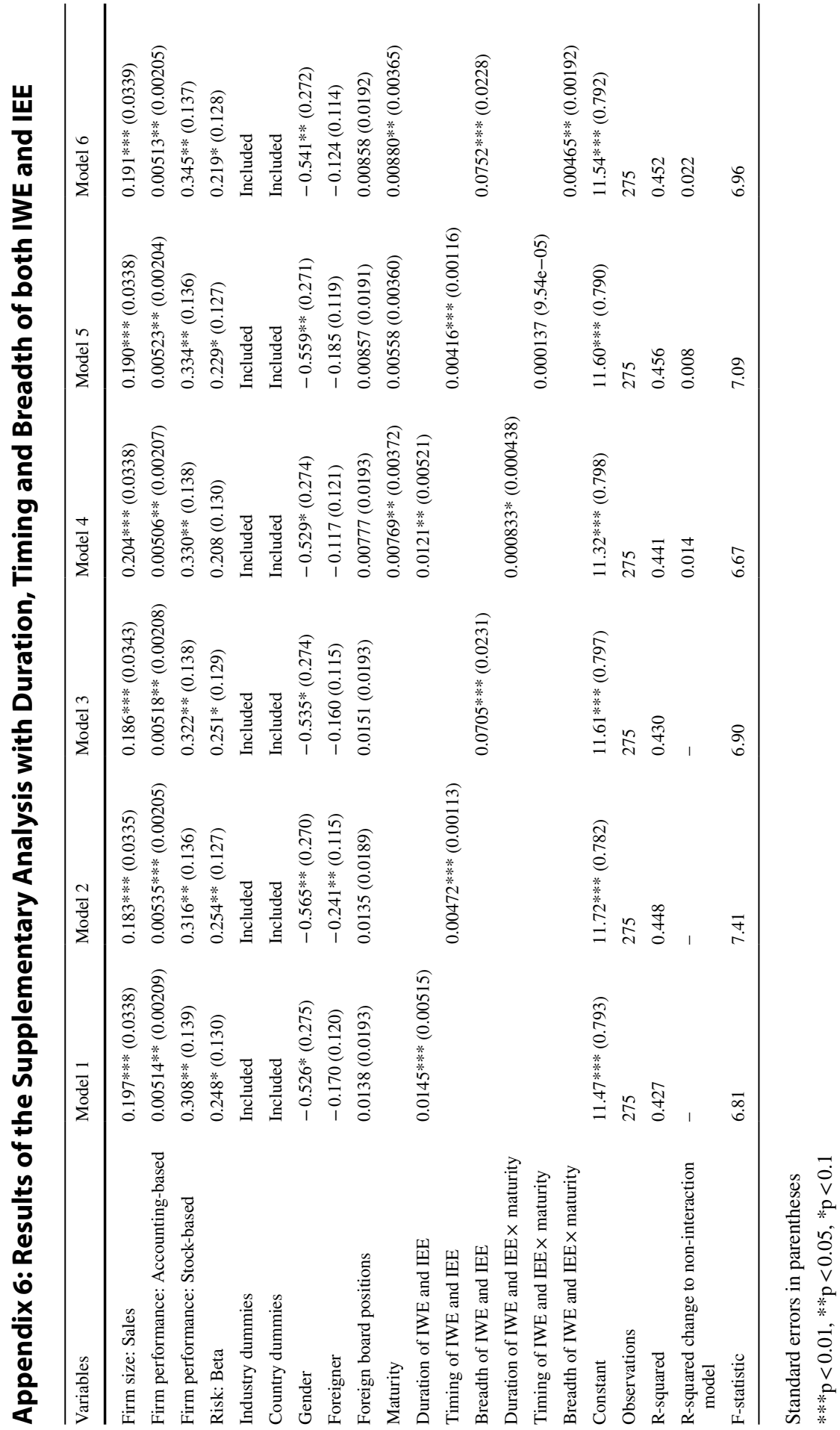


Acknowledgements The authors would like to thank the reviewers and participants of the 10th EIASM Workshop on Top Management Teams and Business Strategy (Passau 2019), the 15th Vaasa Conference on International Business (Vaasa 2019), as well as the 45th EIBA Annual Conference (Leeds 2019) for their valuable comments and suggestions. We also thank Frederic Altfeld, Annalena Düker, Lukas Haueter and Tatiana Solovyeva for support and preparatory work related to this paper, in particular for collecting and preparing parts of the data. The anonymous reviewers and the editors of this journal are to be acknowledged for their very helpful suggestions for improvement and for their support during the review process.

Funding Open Access funding enabled and organized by Projekt DEAL. This research was supported by a grant from ESCP Business School Research Funding.

\section{Compliance with Ethical Standards}

Conflict of interest The authors declare that they have no competing interests.

Open Access This article is licensed under a Creative Commons Attribution 4.0 International License, which permits use, sharing, adaptation, distribution and reproduction in any medium or format, as long as you give appropriate credit to the original author(s) and the source, provide a link to the Creative Commons licence, and indicate if changes were made. The images or other third party material in this article are included in the article's Creative Commons licence, unless indicated otherwise in a credit line to the material. If material is not included in the article's Creative Commons licence and your intended use is not permitted by statutory regulation or exceeds the permitted use, you will need to obtain permission directly from the copyright holder. To view a copy of this licence, visit http://creativecommons.org/licen ses/by/4.0/.

\section{References}

Abatecola, G., \& Cristofaro, M. (2018). Hambrick and Mason's "Upper Echelons Theory": Evolution and open avenues. Journal of Management History, 26(1), 116-136.

Abdi, H., \& Williams, L. J. (2010). Principal component analysis. WIREs Computational Statistics, 2(4), 433-459.

Aguinis, H., Gomez-Mejia, L. R., Martin, G. P., \& Joo, H. (2018). CEO pay is indeed decoupled from CEO performance: Charting a path for the future. Management Research: Journal of the Iberoamerican Academy of Management, 16(1), 117-136.

Aiken, P. S., \& West, S. (1991). Multiple regression: Testing and interpreting interactions. Sage.

Al Ariss, A., Koall, I., Ozbilgin, M., Suutari, V., Cao, L., Hirschi, A., \& Deller, J. (2012). Self-initiated expatriates and their career success. Journal of Management Development, 31(2), 159-172.

Allen, J., \& Barnsley, R. (1993). Streams and tiers: The interaction of ability, maturity, and training in systems with age-dependent recursive selection. The Journal of Human Resources, 28(3), 649-659.

Ambos, B., \& Håkanson, L. (2014). The concept of distance in international management research. Journal of International Management, 20(1), 1-7.

Anderson, R. C., \& Bizjak, J. M. (2003). An empirical examination of the role of the CEO and the compensation committee in structuring executive pay. Journal of Banking and Finance, 27(7), 1323-1348.

Ang, S., \& Van Dyne, L. (Eds.). (2015). Handbook of cultural intelligence. Routledge.

Argyris, C. (1964). Integrating the individual and the organization. Transaction Publishers.

Argyris, C. (1973). Personality and organization theory revisited. Administrative Science Quarterly, 18(2), 141-167.

Arnold, M. C., \& Grasser, R. (2018). What is a fair amount of executive compensation? Outrage potential of two key stakeholder groups. Journal of Business Finance and Accounting, 45(5-6), 651-685.

Athanassiou, N. A., \& Nigh, D. (2002). The impact of the top management team's international business experience on the firm's internationalization: Social networks at work. Management International Review, 42(2), 157-181. 
Athanassiou, N. A., \& Roth, K. (2006). International experience heterogeneity effects on top management team advice networks: A hierarchical analysis. Management International Review, 46(6), 749-770.

Bal, P. M., De Lange, A. H., Jansen, P. G., \& Van Der Velde, M. E. (2008). Psychological contract breach and job attitudes: A meta-analysis of age as a moderator. Journal of Vocational Behavior, 72(1), $143-158$.

Ballas, A. A., \& Tzovas, C. (2010). An empirical investigation of Greek firms' compliance to IFRS disclosure requirements. International Journal of Managerial and Financial Accounting, 2(1), 40-62.

Bandura, A. (1986). Social foundations of thought and action. Prentice-Hall.

Barney, J., Wright, M., \& Ketchen, D. J., Jr. (2001). The resource-based view of the firm: Ten years after 1991. Journal of Management, 27(6), 625-641.

Bebchuk, L. A., Cremers, K. M., \& Peyer, U. C. (2011). The CEO pay slice. Journal of Financial Economics, 102(1), 199-221.

Bebchuk, L. A., Fried, J. M., \& Walker, D. I. (2001). Executive compensation in America: Optimal contracting or extraction of rents? Working Paper w8661, National Bureau of Economic Research.

Becker, G. S. (1964). Human capital: A theoretical and empirical analysis, with special reference to education. University of Chicago Press.

Becker, G. S. (2006). The age of human capital. In H. Lauder, P. Brown, J. Dillabough, \& H. Halsey (Eds.), Education, globalization and social change (pp. 292-295). Oxford University Press.

Benoit, K. (2011). Linear regression models with logarithmic transformations. London School of Economics.

Benson, V., Morgan, S., \& Filippaios, F. (2014). Social career management: Social media and employability skills gap. Computers in Human Behavior, 30, 519-525.

Beugelsdijk, S., \& Welzel, C. (2018). Dimensions and dynamics of national culture: Synthesizing Hofstede with Inglehart. Journal of Cross-Cultural Psychology, 49(10), 1469-1505.

Beugelsdijk, S., Kostova, T., \& Roth, K. (2017). An overview of Hofstede-inspired country-level culture research in international business since 2006. Journal of International Business Studies, 48(1), $30-47$.

Biemann, T., \& Andresen, M. (2010). Self-initiated foreign expatriates versus assigned expatriates: two distinct types of international careers? Journal of Managerial Psychology, 25(4), 430-448.

Biemann, T., \& Wolf, J. (2009). Career patterns of top management team members in five countries: An optimal matching analysis. The International Journal of Human Resource Management, 20(5), 975-991.

Björkman, I., Barner-Rasmussen, W., \& Li, L. (2004). Managing knowledge transfer in MNCs: The impact of headquarters control mechanisms. Journal of International Business Studies, 35(5), 443-455.

Blank, W., Weitzel, J., Blau, G., \& Green, S. G. (1988). A measure of psychological maturity. Group and Organization Management, 13(2), 225-238.

Blau, F. D., \& Kahn, L. M. (2000). Gender differences in pay. Journal of Economic Perspectives, 14(4), 75-99.

Blau, F. D., \& Kahn, L. M. (2003). Understanding international differences in the gender pay gap. Journal of Labor Economics, 21(1), 106-144.

Blaug, M. (1976). The empirical status of human capital theory: A slightly jaundiced survey. Journal of Economic Literature, 14(3), 827-855.

Blyler, M., \& Coff, R. W. (2003). Dynamic capabilities, social capital, and rent appropriation: Ties that split pies. Strategic Management Journal, 24(7), 677-686.

Bonache, J., Brewster, C., \& Suutari, V. (2001). Expatriation: A developing research agenda. Thunderbird International Business Review, 43(1), 3-20.

Boschen, J. F., Duru, A., Gordon, L. A., \& Smith, K. J. (2003). Accounting and stock price performance in dynamic CEO compensation arrangements. The Accounting Review, 78(1), 143-168.

Bro, R., \& Smilde, A. K. (2014). Principal component analysis. Analytical Methods, 6(9), 2812-2831.

Brockman, P., Lee, H. S. G., \& Salas, J. M. (2016). Determinants of CEO compensation: Generalist-specialist versus insider-outsider attributes. Journal of Corporate Finance, 39, 53-77.

Bruce, A., Buck, T., \& Main, B. G. (2005). Top executive remuneration: A view from Europe. Journal of Management Studies, 42(7), 1493-1506.

Bruton, G., Fried, V., \& Hisrich, R. D. (1997). Venture capitalist and CEO dismissal. Entrepreneurship Theory and Practice, 21(3), 41-54. 
Brymer, R. A., Hitt, M. A., \& Schijven, M. (2011). Cognition and human capital: The dynamic interrelationship between knowledge and behaviour. In A. Burton-Jones \& J.-C. Spender (Eds.), The Oxford handbook of human capital (pp. 120-144). Oxford University Press.

Buchanan, B. (1974). Building organizational commitment: The socialization of managers in work organizations. Administrative Science Quarterly, 19(4), 533-546.

Cadman, B., Carter, M. E., \& Hillegeist, S. (2010). The incentives of compensation consultants and CEO pay. Journal of Accounting and Economics, 49(3), 263-280.

Campbell, B. A., Coff, R., \& Kryscynski, D. (2012). Rethinking sustained competitive advantage from human capital. Academy of Management Review, 37(3), 376-395.

Career Trend. (2017). The compensation differences between CEOs vs. CFOs. Retrieved October 11, 2019, from https://careertrend.com/compensation-differences-between-ceos-vs-cfos-12491.html.

Carpenter, M. A., Pollock, T. G., \& Leary, M. M. (2003). Testing a model of reasoned risk-taking: Governance, the experience of principals and agents, and global strategy in high-technology IPO firms. Strategic Management Journal, 24(9), 803-820.

Carpenter, M. A., Sanders, W. G., \& Gregersen, H. B. (2001). Bundling human capital with organizational context: The impact of international assignment experience on multinational firm performance and CEO pay. Academy of Management Journal, 44(3), 493-511.

Cerdin, J. L., \& Pargneux, M. L. (2010). Career anchors: A comparison between organization-assigned and self-initiated expatriates. Thunderbird International Business Review, 52(4), 287-299.

Chen, H. C., \& Naquin, S. S. (2006). An integrative model of competency development, training design, assessment center, and multi-rater assessment. Advances in Developing Human Resources, 8(2), 265-282.

Chen, H. L., Hsu, W. T., \& Chang, C. Y. (2016). Independent directors' human and social capital, firm internationalization and performance implications: An integrated agency-resource dependence view. International Business Review, 25(4), 859-871.

Cheong, A., Sandhu, M. S., Edwards, R., \& Poon, W. C. (2019). Subsidiary knowledge flow strategies and purpose of expatriate assignments. International Business Review, 28(3), 450-462.

Chief Executive. (2004). The global CEO. Retrieved September 12, 2019, from https://chiefexecutive.net/ the-global-ceo_trashed/.

Christmann, A., \& Van Aelst, S. (2006). Robust estimation of Cronbach's alpha. Journal of Multivariate Analysis, 97(7), 1660-1674.

Chron. (2016). The compensation differences between CEOs vs. CFOs. Retrieved October 15, 2019, from https://work.chron.com/compensation-differences-between-ceos-vs-cfos-22835.html.

Clark, A., Oswald, A., \& Warr, P. (1996). Is job satisfaction U-shaped in age? Journal of Occupational and Organizational Psychology, 69(1), 57-81.

Clifford, C. P., \& Lindsey, L. (2016). Blockholder heterogeneity, CEO compensation, and firm performance. Journal of Financial and Quantitative Analysis, 51(5), 1491-1520.

Consultancy.eu. (2018). Average top $100 \mathrm{CEO}$ in Europe earns salary and bonus of $€ 5.8$ million. Retrieved December 3, 2019, from https://www.consultancy.eu/news/2118/average-top-100-ceo-ineurope-earns-salary-bonus-of-58-million.

Contractor, F. J., \& Mudambi, S. M. (2008). The influence of human capital investment on the exports of services and goods: An analysis of the top 25 services outsourcing countries. Management International Review, 48(4), 433-445.

Conyon, M. J., Haß, L. H., Vergauwe, S., \& Zhang, Z. (2019). Foreign experience and CEO compensation. Journal of Corporate Finance, 57, 102-121.

Conyon, M. J., \& Schwalbach, J. (2000). European differences in executive pay and corporate governance. In H. Albach (Ed.), Corporate governance (pp. 97-114). Gabler.

Costanza, D. P., Badger, J. M., Fraser, R. L., Severt, J. B., \& Gade, P. A. (2012). Generational differences in work-related attitudes: A meta-analysis. Journal of Business and Psychology, 27(4), 375-394.

Coughlan, A. T., \& Schmidt, R. M. (1985). Executive compensation, management turnover, and firm performance: An empirical investigation. Journal of Accounting and Economics, 7(1-3), 43-66.

Crossman, J. E., \& Clarke, M. (2010). International experience and graduate employability: Stakeholder perceptions on the connection. Higher Education, 59(5), 599-613.

Custódio, C., Ferreira, M. A., \& Matos, P. (2013). Generalists versus specialists: Lifetime work experience and chief executive officer pay. Journal of Financial Economics, 108(2), 471-492.

Cuypers, I. R., Ertug, G., Heugens, P. P., Kogut, B., \& Zou, T. (2018). The making of a construct: Lessons from 30 years of the Kogut and Singh cultural distance index. Journal of International Business Studies, 49(9), 1138-1153. 
Daily, C. M., Certo, S. T., \& Dalton, D. R. (2000). International experience in the executive suite: The path to prosperity? Strategic Management Journal, 21(4), 515-523.

Dane, E. (2010). Reconsidering the trade-off between expertise and flexibility: A cognitive entrenchment perspective. Academy of Management Review, 35(4), 579-603.

Datta, S., \& Iskandar-Datta, M. (2014). Upper-echelon executive human capital and compensation: Generalist vs specialist skills. Strategic Management Journal, 35(12), 1853-1866.

David, P., \& Lopez, J. (2001). Knowledge, capabilities and human capital formation in economic growth. Working Paper 01/13, New Zealand Treasury.

Davis, G. F., \& Cobb, J. A. (2010). Resource dependence theory: Past and future. Research in the Sociology of Organizations, 28, 21-42.

Deckop, J. R. (1988). Determinants of chief executive officer compensation. Industrial and Labor Relations Review, 41(2), 215-226.

Demir, R., \& Söderman, S. (2007). Skills and complexity in management of IJVs: Exploring Swedish managers' experiences in China. International Business Review, 16(2), 229-250.

Diamond, M. A. (1986). Resistance to change: A psychoanalytic critique of Argyris and Schon's contributions to organization theory and intervention. Journal of Management Studies, 23(5), 543-562.

Dickmann, M., \& Harris, H. (2005). Developing career capital for global careers: The role of international assignments. Journal of World Business, 40(4), 399-408.

Dobbs, R. L., Sun, J. Y., \& Roberts, P. B. (2008). Human capital and screening theories: Implications for human resource development. Advances in Developing Human Resources, 10(6), 788-801.

Drabe, D., Hauff, S., \& Richter, N. F. (2015). Job satisfaction in aging workforces: An analysis of the USA, Japan and Germany. The International Journal of Human Resource Management, 26(6), 783-805.

Drees, J. M., \& Heugens, P. P. (2013). Synthesizing and extending resource dependence theory: A metaanalysis. Journal of Management, 39(6), 1666-1698.

Dyl, E. A. (1988). Corporate control and management compensation: Evidence on the agency problem. Managerial and Decision Economics, 9(1), 21-25.

Eggers, J. P., \& Kaplan, S. (2009). Cognition and renewal: Comparing CEO and organizational effects on incumbent adaptation to technical change. Organization Science, 20(2), 461-477.

Eisinga, R., Te Grotenhuis, M., \& Pelzer, B. (2013). The reliability of a two-item scale: Pearson, Cronbach, or Spearman-Brown? International Journal of Public Health, 58(4), 637-642.

Falato, A., Li, D., \& Milbourn, T. (2015). Which skills matter in the market for CEOs? Evidence from pay for CEO credentials. Management Science, 61(12), 2845-2869.

Faulkender, M., Kadyrzhanova, D., Prabhala, N., \& Senbet, L. (2010). Executive compensation: An overview of research on corporate practices and proposed reforms. Journal of Applied Corporate Finance, 22(1), 107-118.

Fernandes, N., Ferreira, M. A., Matos, P., \& Murphy, K. J. (2013). Are US CEOs paid more? New international evidence. The Review of Financial Studies, 26(2), 323-367.

Filatotchev, I., \& Allcock, D. (2010). Corporate governance and executive remuneration: A contingency framework. Academy of Management Perspectives, 24(1), 20-33.

Financial Times. (2013). How valuable is international work experience? Retrieved October 5, 2019, from https://www.ft.com/content/89b6ebca-3a35-11e3-9243-00144feab7de.

Financial Times. (2015). FT 5002015 introduction and methodology. Retrieved October 4, 2019, from https://www.ft.com/content/1fda5794-169f-11e5-b07f-00144feabdc0.

Finkelstein, S., \& Hambrick, D. C. (1989). Chief executive compensation: A study of the intersection of markets and political processes. Strategic Management Journal, 10(2), 121-134.

Firth, M., Fung, P. M., \& Rui, O. M. (2006). Corporate performance and CEO compensation in China. Journal of Corporate Finance, 12(4), 693-714.

Fitz-Enz, J. (2000). The ROI human capital: Measuring the economic value of employee performance. American Management Association.

Flouri, E., \& Buchanan, A. (2002). The role of work-related skills and career role models in adolescent career maturity. The Career Development Quarterly, 51(1), 36-43.

Ford, J. K., Quiñones, M. A., Sego, D. J., \& Sorra, J. S. (1992). Factors affecting the opportunity to perform trained tasks on the job. Personnel Psychology, 45(3), 511-527.

Frydman, C., \& Jenter, D. (2010). CEO compensation. Annual Review of Financial Economics, 2(1), 75-102.

Gathmann, C., \& Schönberg, U. (2010). How general is human capital? A task-based approach. Journal of Labor Economics, 28(1), 1-49. 
Gaugler, B. B., Rosenthal, D. B., Thornton, G. C., \& Bentson, C. (1987). Meta-analysis of assessment center validity. Journal of Applied Psychology, 72(3), 493-511.

Georgakakis, D., Dauth, T., \& Ruigrok, W. (2016). Too much of a good thing: Does international experience variety accelerate or delay executives' career advancement? Journal of World Business, 51(3), 425-437.

Gibbons, R., \& Waldman, M. (2004). Task-specific human capital. American Economic Review, 94(2), 203-207.

Godart, F. C., Maddux, W. W., Shipilov, A. V., \& Galinsky, A. D. (2015). Fashion with a foreign flair: Professional experiences abroad facilitate the creative innovations of organizations. Academy of Management Journal, 58(1), 195-220.

Gomez-Mejia, L. R., Tosi, H., \& Hinkin, T. (1987). Managerial control, performance, and executive compensation. Academy of Management Journal, 30(1), 51-70.

Gormley, T. A., Matsa, D. A., \& Milbourn, T. (2013). CEO compensation and corporate risk: Evidence from a natural experiment. Journal of Accounting and Economics, 56(2-3), 79-101.

Greco, S., Ishizaka, A., Tasiou, M., \& Torrisi, G. (2019). On the methodological framework of composite indices: A review of the issues of weighting, aggregation, and robustness. Social Indicators Research, 141(1), 61-94.

Grund, C. (2015). Gender pay gaps among highly educated professionals-Compensation components do matter. Labour Economics, 34, 118-126.

Grundstein, M. (2008). Assessing the enterprise's knowledge management maturity level. International Journal of Knowledge and Learning, 4(5), 415-426.

Gupta, A. K., \& Govindarajan, V. (2002). Cultivating a global mindset. Academy of Management Perspectives, 16(1), 116-126.

Haans, R. F., Pieters, C., \& He, Z. L. (2016). Thinking about U: Theorizing and testing U-and inverted U-shaped relationships in strategy research. Strategic Management Journal, 37(7), 1177-1195.

Haas, M. R. (2006). Acquiring and applying knowledge in transnational teams: The roles of cosmopolitans and locals. Organization Science, 17(3), 367-384.

Hagan, C. M., Konopaske, R., Bernardin, H. J., \& Tyler, C. L. (2006). Predicting assessment center performance with 360-degree, top-down, and customer-based competency assessments. Human Resource Management, 45(3), 357-390.

Hambrick, D. C., \& Quigley, T. J. (2014). Toward more accurate contextualization of the CEO effect on firm performance. Strategic Management Journal, 35(4), 473-491.

Hamilton, B. H., \& Nickerson, J. A. (2003). Correcting for endogeneity in strategic management research. Strategic Organization, 1(1), 51-78.

Hamori, M., \& Koyuncu, B. (2011). Career advancement in large organizations in Europe and the United States: Do international assignments add value? The International Journal of Human Resource Management, 22(4), 843-862.

Harris, D., \& Helfat, C. (1997). Specificity of CEO human capital and compensation. Strategic Management Journal, 18(11), 895-920.

Hauke, J., \& Kossowski, T. (2011). Comparison of values of Pearson's and Spearman's correlation coefficients on the same sets of data. Quaestiones Geographicae, 30(2), 87-93.

Hayes, A. F. (2017). Introduction to mediation, moderation and conditional process analysis: A regression-based approach. The Guilford Press.

Heath, D. H. (1976). Adolescent and adult predictors of vocational adaptation. Journal of Vocational Behavior, 9(1), 1-19.

Heckman, J. J. (2000). Policies to foster human capital. Research in Economics, 54(1), 3-56.

Heijltjes, M., Olie, R., \& Glunk, U. (2003). Internationalization of top management teams in Europe. European Management Journal, 21(1), 89-97.

Hermanson, D. R., Tompkins, J. G., Veliyath, R., \& Ye, Z. (2012). The compensation committee process. Contemporary Accounting Research, 29(3), 666-709.

Herr, E. L., \& Enderlein, T. E. (1976). Vocational maturity: The effects of school, grade, curriculum and sex. Journal of Vocational Behavior, 8(2), 227-238.

Herrmann, P., \& Datta, D. K. (2005). Relationships between top management team characteristics and international diversification: An empirical investigation. British Journal of Management, 16(1), 69-78.

Herrmann, P., \& Datta, D. K. (2006). CEO experiences: Effects on the choice of FDI entry mode. Journal of Management Studies, 43(4), 755-778. 
Hersey, P., \& Blanchard, K. H. (1969). Life cycle theory of leadership. Training and Development Journal, 23(5), 26-34.

Herzberg, F., Mausnes, B., Peterson, R. O., \& Capwell, D. F. (1957). Job attitudes; Review of research and opinion. Psychological Service of Pittsburgh.

Hill, C. W., \& Phan, P. (1991). CEO tenure as a determinant of CEO pay. Academy of Management Journal, 34(3), 707-717.

Hillman, A. J., Cannella, A. A., \& Paetzold, R. L. (2000). The resource dependence role of corporate directors: Strategic adaptation of board composition in response to environmental change. Journal of Management Studies, 37(2), 235-256.

Hillman, A. J., Withers, M. C., \& Collins, B. J. (2009). Resource dependence theory: A review. Journal of Management, 35(6), 1404-1427.

Hitt, L., Jin, F., \& Wu, L. (2015). Data skills and value of social media: Evidence from large-sample firm value analysis. ICIS.

Hitt, M. A., Beamish, P. W., Jackson, S. E., \& Mathieu, J. E. (2007). Building theoretical and empirical bridges across levels: Multilevel research in management. Academy of Management Journal, 50(6), 1385-1399.

Hitt, M. A., Bierman, L., Shimizu, K., \& Kochhar, R. (2001). Direct and moderating effects of human capital on strategy and performance in professional service firms: A resource-based perspective. Academy of Management Journal, 44(1), 13-28.

Hogan, R., \& Roberts, B. W. (2004). A socioanalytic model of maturity. Journal of Career Assessment, 12(2), 207-217.

Hogan, T. D., \& McPheters, L. R. (1980). Executive compensation: Performance versus personal characteristics. Southern Economic Journal, 46(4), 1060-1068.

Hooghiemstra, R., Hermes, N., Oxelheim, L., \& Randøy, T. (2019). Strangers on the board: The impact of board internationalization on earnings management of Nordic firms. International Business Review, 28(1), 119-134.

Hult. (2020). Career mapping: How to become an executive in the next 5 years. Retrieved January 27, 2020, from https://www.hult.edu/blog/career-mapping-how-to-become-an-execu tive-in-the-next-5-years/.

Hunt, J. W., \& Saul, P. N. (1975). The relationship of age, tenure, and job satisfaction in males and females. Academy of Management Journal, 18(4), 690-702.

Igarashi, H., \& Saito, H. (2014). Cosmopolitanism as cultural capital: Exploring the intersection of globalization, education and stratification. Cultural Sociology, 8(3), 222-239.

Imbens, G. W., \& Rubin, D. B. (2015). Causal inference for statistics, social, and biomedical sciences: An introduction. Cambridge University Press.

Inkson, K., \& Arthur, M. B. (2001). How to be a successful career capitalist. Organizational Dynamics, 30(1), 48-61.

Inkson, K., Arthur, M. B., Pringle, J., \& Barry, S. (1997). Expatriate assignment versus overseas experience: Contrasting models of international human resource development. Journal of World Business, 32(4), 351-368.

Izenman, A. J. (2013). Modern multivariate statistical techniques: Regression, classification, and manifold learning. Springer.

Jiang, F., Ananthram, S., \& Li, J. (2018). Global mindset and entry mode decisions: Moderating roles of managers' decision-making style and managerial experience. Management International Review, 58(3), 413-447.

Jokinen, T., Brewster, C., \& Suutari, V. (2008). Career capital during international work experiences: Contrasting self-initiated expatriate experiences and assigned expatriation. The International Journal of Human Resource Management, 19(6), 979-998.

Jones, E. (2013). Internationalization and employability: The role of intercultural experiences in the development of transferable skills. Public Money and Management, 33(2), 95-104.

Jongjaroenkamol, P., \& Laux, V. (2017). Insider versus outsider CEOs, executive compensation, and accounting manipulation. Journal of Accounting and Economics, 63(2-3), 253-261.

Judge, T. A., Cable, D. M., Boudreau, J. W., \& Bretz, R. D., Jr. (1995). An empirical investigation of the predictors of executive career success. Personnel Psychology, 48(3), 485-519.

Kaplan, S. N. (2008). Are US CEOs overpaid? Academy of Management Perspectives, 22(2), 5-20.

Kato, T., \& Long, C. (2006). CEO turnover, firm performance, and enterprise reform in China: Evidence from micro data. Journal of Comparative Economics, 34(4), 796-817. 
Kearney, E. (2008). Age differences between leader and followers as a moderator of the relationship between transformational leadership and team performance. Journal of Occupational and Organizational Psychology, 81(4), 803-811.

Khanna, P., Jones, C. D., \& Boivie, S. (2014). Director human capital, information processing demands, and board effectiveness. Journal of Management, 40(2), 557-585.

Kish-Gephart, J. J., \& Campbell, J. T. (2015). You don't forget your roots: The influence of CEO social class background on strategic risk taking. Academy of Management Journal, 58(6), 1614-1636.

Kitchner, K. S. (1983). Cognition, metacognition, and epistemic cognition. Human Development, 26(4), 222-232.

Kitsantas, A. (2004). Studying abroad: The role of college students' goals on the development of cross-cultural skills and global understanding. College Student Journal, 38(3), 441-452.

Klimoski, R., \& Brickner, M. (1987). Why do assessment centers work? The puzzle of assessment center validity. Personnel Psychology, 40(2), 243-260.

Kluger, A. N., \& DeNisi, A. (1996). The effects of feedback interventions on performance: A historical review, a meta-analysis, and a preliminary feedback intervention theory. Psychological Bulletin, $119(2), 254$.

Knight, G. A., \& Cavusgil, S. T. (2004). Innovation, organizational capabilities, and the born-global firm. Journal of International Business Studies, 35(2), 124-141.

Kogut, B., \& Singh, H. (1988). The effect of national culture on the choice of entry mode. Journal of International Business Studies, 19(3), 411-432.

Kohler, U., \& Kreuter, F. (2012). Data analysis using Stata (3rd ed.). Stata Press.

Kooij, D. T., De Lange, A. H., Jansen, P. G., Kanfer, R., \& Dikkers, J. S. (2011). Age and work-related motives: Results of a meta-analysis. Journal of Organizational Behavior, 32(2), 197-225.

Kopalle, P. K., \& Lehmann, D. R. (1997). Alpha inflation? The impact of eliminating scale items on Cronbach's alpha. Organizational Behavior and Human Decision Processes, 70(3), 189-197.

Kostiuk, P. F. (1990). Firm size and executive compensation. The Journal of Human Resources, 25(1), 90-105.

Kraaijenbrink, J. (2011). Human capital in the resource-based view. In A. Burton-Jones \& J.-C. Spender (Eds.), The Oxford handbook of human capital (pp. 218-237). Oxford University Press.

Kulich, C., Trojanowski, G., Ryan, M. K., Haslam, S. A., \& Renneboog, L. D. (2011). Who gets the carrot and who gets the stick? Evidence of gender disparities in executive remuneration. Strategic Management Journal, 32(3), 301-321.

Kwon, S. W., \& Adler, P. S. (2014). Social capital: Maturation of a field of research. Academy of Management Review, 39(4), 412-422.

Lazear, E. P. (2009). Firm-specific human capital: A skill-weights approach. Journal of Political Economy, 117(5), 914-940.

Le, H., Brewster, C., Demirbag, M., \& Wood, G. (2013). Management compensation systems in MNCs and domestic firms. Management International Review, 53(5), 741-762.

Le, S., \& Kroll, M. (2017). CEO international experience: Effects on strategic change and firm performance. Journal of International Business Studies, 48(5), 573-595.

Lee, J. H., \& Roberts, M. J. (2015). International returnees as outside directors: A catalyst for strategic adaptation under institutional pressure. International Business Review, 24(4), 594-604.

Lepak, D. P., \& Snell, S. A. (1999). The human resource architecture: Toward a theory of human capital allocation and development. Academy of Management Review, 24(1), 31-48.

Li, M., \& Patel, P. C. (2019). Jack of all, master of all? CEO generalist experience and firm performance. The Leadership Quarterly, 30(3), 320-334.

Lievens, F., Harris, M. M., Van Keer, E., \& Bisqueret, C. (2003). Predicting cross-cultural training performance: the validity of personality, cognitive ability, and dimensions measured by an assessment center and a behavior description interview. Journal of Applied Psychology, 88(3), 476-489.

Lin, D., Kuo, H. C., \& Wang, L. H. (2013). Chief executive compensation: An empirical study of fat cat CEOs. The International Journal of Business and Finance Research, 7(2), 27-42.

Lind, J. T., \& Mehlum, H. (2010). With or without U? The appropriate test for a U-shaped relationship. Oxford Bulletin of Economics and Statistics, 72(1), 109-118.

Lippert, R. L., \& Porter, G. (1997). Understanding CEO pay: A test of two pay-to-performance sensitivity measures with alternative measures of alignment and influence. Journal of Business Research, 40(2), 127-138. 
Lu, J. W., \& Beamish, P. W. (2001). The internationalization and performance of SMEs. Strategic Management Journal, 22(6-7), 565-586.

Mackey, A., Molloy, J. C., \& Morris, S. S. (2014). Scarce human capital in managerial labor markets. Journal of Management, 40(2), 399-421.

Maddux, W. W., \& Galinsky, A. D. (2009). Cultural borders and mental barriers: The relationship between living abroad and creativity. Journal of Personality and Social Psychology, 96(5), 1047-1061.

Maddux, W. W., Lu, J. G., Affinito, S. J., \& Galinsky, A. D. (2020). Multicultural experiences: A systematic review and new theoretical framework. Academy of Management Annals (in press).

Magnusson, P., \& Boggs, D. J. (2006). International experience and CEO selection: An empirical study. Journal of International Management, 12(1), 107-125.

Mahoney, J. T., \& Kor, Y. Y. (2015). Advancing the human capital perspective on value creation by joining capabilities and governance approaches. Academy of Management Perspectives, 29(3), 296-308.

Main, B. G., O'Reilly, C. A., \& Wade, J. (1995). The CEO, the board of directors and executive compensation: Economic and psychological perspectives. Industrial and Corporate Change, 4(2), 293-332.

McKnight, P. J., Tomkins, C., Weir, C., \& Hobson, D. (2000). CEO age and top executive pay: A UK empirical study. Journal of Management and Governance, 4(3), 173-187.

McKnight, P., \& Tomkins, C. (2004). The implications of firm and individual characteristics on CEO pay. European Management Journal, 22(1), 27-40.

McNulty, Y., \& De Cieri, H. (2011). Global mobility in the 21st century: Conceptualising expatriate return on investment in global firms. Management International Review, 51(6), 897-919.

Mehran, H. (1995). Executive compensation structure, ownership, and firm performance. Journal of Financial Economics, 38(2), 163-184.

Mendenhall, M. E., \& Stahl, G. K. (2000). Expatriate training and development: where do we go from here? Human Resource Management, 39(2-3), 251-265.

Mendenhall, W., \& Sincich, T. (2011). A second course in statistics: Regression analysis (7th ed.). Pearson.

Miller, D., Xu, X., \& Mehrotra, V. (2015). When is human capital a valuable resource? The performance effects of Ivy League selection among celebrated CEOs. Strategic Management Journal, 36(6), 930-944.

Miller, J. S., Wiseman, R. M., \& Gomez-Mejia, L. R. (2002). The fit between CEO compensation design and firm risk. Academy of Management Journal, 45(4), 745-756.

Mishra, D. R. (2014). The dark side of CEO ability: CEO general managerial skills and cost of equity capital. Journal of Corporate Finance, 29, 390-409.

Morrow, P. C., \& McElroy, J. C. (1987). Work commitment and job satisfaction over three career stages. Journal of Vocational Behavior, 30(3), 330-346.

Murphy, K. J. (2013). Executive compensation: Where we are, and how we got there. In G. M. Constantinides, M. Harris, \& R. M. Stulz (Eds.), Handbook of the economics of finance (pp. 211-356). Elsevier.

Murphy, K. J., \& Sandino, T. (2010). Executive pay and "independent" compensation consultants. Journal of Accounting and Economics, 49(3), 247-262.

Nadkarni, P. M., Ohno-Machado, L., \& Chapman, W. W. (2011). Natural language processing: an introduction. Journal of the American Medical Informatics Association, 18(5), 544-551.

Nafukho, F. M., Hairston, N., \& Brooks, K. (2004). Human capital theory: Implications for human resource development. Human Resource Development International, 7(4), 545-551.

Nakara, W. A., Benmoussa, F. Z., \& Jaouen, A. (2012). Entrepreneurship and social media marketing: evidence from French small business. International Journal of Entrepreneurship and Small Business, 16(4), 386-405.

Neal, D. (1995). Industry-specific human capital: Evidence from displaced workers. Journal of Labor Economics, 13(4), 653-677.

Ng, K.-Y., Van Dyne, L. \& Ang, S. (2009). Developing global leaders: The role of international experience and cultural intelligence. In Mobley, W.H., Wang, Y. and Li, M. (Eds.), Advances in Global Leadership (Vol. 5) (pp. 225-250), Emerald Group Publishing Limited.

Ng, K.-Y., Tan, M. L., \& Ang, S. (2011). Global culture capital and cosmopolitan human capital: The effects of global mindset and organizational routines on cultural intelligence and international experience. In A. Burton-Jones \& J.-C. Spender (Eds.), The Oxford handbook of human capital (pp. 96-119). Oxford University Press. 
Nielsen, S. (2010). Top management team internationalization and firm performance. Management International Review, 50(2), 185-206.

Nienhüser, W. (2008). Resource dependence theory-How well does it explain behavior of organizations? Management Revue, 19(1-2), 9-32.

O'Brien, R. M. (2007). A caution regarding rules of thumb for variance inflation factors. Quality and Quantity, 41(5), 673-690.

Oesterle, M. J., Elosge, C., \& Elosge, L. (2016). Me, myself and I: The role of CEO narcissism in internationalization decisions. International Business Review, 25(5), 1114-1123.

Otten, J., Carberry, E., van Essen, M., \& Van Oosterhout, H. (2012). Towards an institutional theory of managerial power on CEO compensation: An international test. Academy of Management Proceedings, 2012(1), 15814.

Oxelheim, L., \& Randøy, T. (2005). The Anglo-American financial influence on CEO compensation in non-Anglo-American firms. Journal of International Business Studies, 36(4), 470-483.

PageGroup. (2019). Oliver Watson. Retrieved September 12, 2019, from https://www.page.com/inves tors/responsibilities/directors/executive-board/oliver-watson.aspx.

Pasupathi, M., Weeks, T., \& Rice, C. (2006). Reflecting on life: Remembering as a major process in adult development. Journal of Language and Social Psychology, 25(3), 244-263.

Peng, M. W. (2001). The resource-based view and international business. Journal of Management, 27(6), 803-829.

Peng, M. W., Sun, S. L., \& Markóczy, L. (2015). Human capital and CEO compensation during institutional transitions. Journal of Management Studies, 52(1), 117-147.

Perry, T., \& Zenner, M. (2000). CEO Compensation in the 1990's: Shareholder Alignment or Shareholder Expropriation. Wake Forest Law Review, 35, 123-152.

Peteraf, M. A. (1993). The cornerstones of competitive advantage: A resource-based view. Strategic Management Journal, 14(3), 179-191.

Peterson, R. A. (1994). A meta-analysis of Cronbach's coefficient alpha. Journal of Consumer Research, 21(2), 381-391.

Pfeffer, J., \& Salancik, G. R. (1978). The external control of organizations: A resource dependence perspective. Harper \& Row.

Ployhart, R. E., \& Moliterno, T. P. (2011). Emergence of the human capital resource: A multilevel model. Academy of Management Review, 36(1), 127-150.

Point, S. (2005). Accountability, transparency and performance: Comparing annual report disclosures on CEO pay across Europe. In S. Tyson \& F. Bournois (Eds.), Top pay and performance: International and strategic approach (pp. 57-84). Butterworth-Heinemann.

Porac, J. F., Wade, J. B., \& Pollock, T. G. (1999). Industry categories and the politics of the comparable firm in CEO compensation. Administrative Science Quarterly, 44(1), 112-144.

Posner, R. A. (2008). Are American CEOs overpaid, and if so, what if anything should be done about it. Duke Law Journal, 58, 1013-1047.

Prendergast, C. (1993). The role of promotion in inducing specific human capital acquisition. Quarterly Journal of Economics, 108(2), 523-534.

Qin, B. (2012). The influence of firm and executive characteristics on performance-vested stock option grants. International Business Review, 21(5), 906-928.

Ramaswami, A., Carter, N. M., \& Dreher, G. F. (2016). Expatriation and career success: A human capital perspective. Human Relations, 69(10), 1959-1987.

Ramaswamy, K., Veliyath, R., \& Gomes, L. (2000). A study of the determinants of CEO compensation in India. Management International Review, 40(2), 167-191.

Randøy, T., \& Nielsen, J. (2002). Company performance, corporate governance, and CEO compensation in Norway and Sweden. Journal of Management and Governance, 6(1), 57-81.

Reiche, B. S., Lee, Y., \& Allen, D. G. (2019). Actors, structure, and processes: A review and conceptualization of global work integrating IB and HRM research. Journal of Management, 45(2), 359-383.

Rickley, M. (2019). Cultural generalists and cultural specialists: Examining international experience portfolios of subsidiary executives in multinational firms. Journal of Management, 45(2), 384-416.

Rose, N. L., \& Shepard, A. (1994). Firm diversification and CEO compensation: Managerial ability or executive entrenchment? Working Paper w4723, National Bureau of Economic Research.

Roth, K. (1995). Managing international interdependence: CEO characteristics in a resource-based framework. Academy of Management Journal, 38(1), 200-231. 
Sambharya, R. B. (1996). Foreign experience of top management teams and international diversification strategies of US multinational corporations. Strategic Management Journal, 17(9), 739-746.

Savickas, M. L. (2001). A developmental perspective on vocational behaviour: Career patterns, salience, and themes. International Journal for Educational and Vocational Guidance, 1(1-2), 49-57.

Schlepphorst, S., Koetter, E. C., Werner, A., Soost, C., \& Moog, P. (2020). International assignments of employees and entrepreneurial intentions: The mediating role of human capital, social capital and career prospects. International Journal of Entrepreneurial Behavior \& Research, 26(6), 1259-1279.

Schlossarek, M., Syrovátka, M., \& Vencálek, O. (2019). The importance of variables in composite indices: A contribution to the methodology and application to development indices. Social Indicators Research, 145(3), 1125-1160.

Schmid, S., \& Altfeld, F. (2018). International work experience and compensation: Is more always better for CFOs? European Management Journal, 36(4), 530-543.

Schmid, S., Altfeld, F., \& Dauth, T. (2018). Americanization as a driver of CEO pay in Europe: The moderating role of CEO power. Journal of World Business, 53(4), 433-451.

Schmid, S., \& Wurster, D. J. (2016). Are international top executives paid more? Empirical evidence on fixed and variable compensation in management boards of German MNCs. European Journal of International Management, 10(1), 25-53.

Schmid, S., \& Wurster, D. J. (2017). International work experience: Is it really accelerating the way to the management board of MNCs? International Business Review, 26(5), 991-1008.

Schmidt, F. L., \& Hunter, J. (2004). General mental ability in the world of work: Occupational attainment and job performance. Journal of Personality and Social Psychology, 86(1), 162-173.

Schulz, E., Chowdhury, S., \& Van de Voort, D. (2013). Firm productivity moderated link between human capital and compensation: The significance of task-specific human capital. Human Resource Management, 52(3), 423-439.

Selmer, J. (2001). Expatriate selection: back to basics? International Journal of Human Resource Management, 12(8), 1219-1233.

Shaffer, M. A., Kraimer, M. L., Chen, Y. P., \& Bolino, M. C. (2012). Choices, challenges, and career consequences of global work experiences: A review and future agenda. Journal of Management, 38(4), $1282-1327$.

Sheldon, K. M., Houser-Marko, L., \& Kasser, T. (2006). Does autonomy increase with age? Comparing the goal motivations of college students and their parents. Journal of Research in Personality, 40(2), $168-178$

Sheldon, K. M., \& Kasser, T. (2001). Getting older, getting better? Personal strivings and psychological maturity across the life span. Developmental Psychology, 37(4), 491-501.

Shenkar, O. (2001). Cultural distance revisited: Towards a more rigorous conceptualization and measurement of cultural differences. Journal of International Business Studies, 32(3), 519-535.

Simpson, P. A., Greller, M. M., \& Stroh, L. K. (2002). Variations in human capital investment activity by age. Journal of Vocational Behavior, 61(1), 109-138.

Slater, D. J., \& Dixon-Fowler, H. R. (2009). CEO international assignment experience and corporate social performance. Journal of Business Ethics, 89(3), 473-489.

Slaughter, S. A., Ang, S., \& Fong Boh, W. (2007). Firm-specific human capital and compensation organizational tenure profiles: An archival analysis of salary data for it. Human Resource Management, 46(3), 373-394.

Smirnova, A. S., \& Zavertiaeva, M. A. (2017). Which came first, CEO compensation or firm performance? The causality dilemma in European companies. Research in International Business and Finance, 42, 658-673.

Sousa, C. M., \& Bradley, F. (2006). Cultural distance and psychic distance: Two peas in a pod? Journal of International Marketing, 14(1), 49-70.

Steinberg, L., \& Cauffman, E. (1996). Maturity of judgment in adolescence: Psychosocial factors in adolescent decision making. Law and Human Behavior, 20(3), 249-272.

Sturman, M. C. (2003). Searching for the inverted U-shaped relationship between time and performance: Meta-analyses of the experience/performance, tenure/performance, and age/performance relationships. Journal of Management, 29(5), 609-640.

Super, D. E., \& Kidd, J. M. (1979). Vocational maturity in adulthood: Toward turning a model into a measure. Journal of Vocational Behavior, 14(3), 255-270.

Takeuchi, R., \& Chen, J. (2013). The impact of international experiences for expatriates' cross-cultural adjustment: A theoretical review and a critique. Organizational Psychology Review, 3(3), 248-290. 
Takeuchi, R., Tesluk, P. E., \& Marinova, S. V. (2006). Role of international experiences in the development of cultural intelligence. In S. Dey \& V. N. Posa (Eds.), Cultural intelligence: An introduction (pp. 56-91). ICFAI University Press.

Takeuchi, R., Tesluk, P. E., Yun, S., \& Lepak, D. P. (2005). An integrative view of international experience. Academy of Management Journal, 48(1), 85-100.

Takeuchi, R., Wang, M., Marinova, S. V., \& Yao, X. (2009). Role of domain-specific facets of perceived organizational support during expatriation and implications for performance. Organization Science, 20(3), 621-634.

Tesluk, P. E., \& Jacobs, R. R. (1998). Toward an integrated model of work experience. Personnel Psychology, 51(2), 321-355.

The CEO Magazine. (2019). The importance of international experience for CEOs. Retrieved September 17, 2019, from https://www.theceomagazine.com/business/management-leadership/the-importance-ofinternational-experience-for-ceos/.

The Guardian. (2019). Shell CEO’s pay more than doubles to £17.2m. Retrieved September 5, 2019, from https://www.theguardian.com/business/2019/mar/14/shell-ceo-ben-van-beurden-pay-doubles-oil.

Thompson, E. R., \& Phua, F. T. (2012). A brief index of affective job satisfaction. Group \& Organization Management, 37(3), 275-307.

Tien, C., Chen, C. N., \& Chuang, C. M. (2013). A study of CEO power, pay structure, and firm performance. Journal of Management and Organization, 19(4), 424-453.

Tosi, H. L., \& Gomez-Mejia, L. R. (1994). CEO compensation monitoring and firm performance. Academy of Management Journal, 37(4), 1002-1016.

Tosi, H. L., \& Greckhamer, T. (2004). Culture and CEO compensation. Organization Science, 15(6), 657-670.

Tosi, H. L., Werner, S., Katz, J. P., \& Gomez-Mejia, L. R. (2000). How much does performance matter? A meta-analysis of CEO pay studies. Journal of Management, 26(2), 301-339.

Townsend, A. M., Scott, K. D., \& Markham, S. E. (1990). An examination of country and culture-based differences in compensation practices. Journal of International Business Studies, 21(4), 667-678.

Tremblay, M., \& Chenevert, D. (2005). The effectiveness of compensation strategies in international technology intensive firms. International Journal of Technology Management, 31(3-4), 222-239.

Tsoukas, H. (1996). The firm as a distributed knowledge system: A constructionist approach. Strategic Management Journal, 17(S2), 11-25.

Tung, R. L. (1998). American expatriates abroad: From neophytes to cosmopolitans. Journal of World Business, 33(2), 125-144.

Van Essen, M., Otten, J., \& Carberry, E. J. (2015). Assessing managerial power theory: A meta-analytic approach to understanding the determinants of CEO compensation. Journal of Management, 41(1), 164-202.

Van Veen, K., \& Marsman, I. (2008). How international are executive boards of European MNCs? Nationality diversity in 15 European countries. European Management Journal, 26(3), 188-198.

Veiga, J. F. (1981). Plateaued versus nonplateaued managers: Career patterns, attitudes, and path potential. Academy of Management Journal, 24(3), 566-578.

Veliyath, R. (1999). Top management compensation and shareholder returns: unravelling different models of the relationship. Journal of Management Studies, 36(1), 123-143.

Volonté, C., \& Gantenbein, P. (2016). Directors' human capital, firm strategy, and firm performance. Journal of Management \& Governance, 20(1), 115-145.

Weick, K. E. (1995). Sensemaking in organizations. Sage.

Wernerfelt, B. (1984). A resource-based view of the firm. Strategic Management Journal, 5(2), 171-180.

Westphal, J. D., \& Zajac, E. J. (1995). Who shall govern? CEO/board power, demographic similarity, and new director selection. Administrative Science Quarterly, 40(1), 60-83.

Wiers-Jenssen, J. (2008). Does higher education attained abroad lead to international jobs? Journal of Studies in International Education, 12(2), 101-130.

Wiese, B. S., Freund, A. M., \& Baltes, P. B. (2002). Subjective career success and emotional well-being: Longitudinal predictive power of selection, optimization, and compensation. Journal of Vocational Behavior, 60(3), 321-335.

Williams, T. R. (2005). Exploring the impact of study abroad on students' intercultural communication skills: Adaptability and sensitivity. Journal of Studies in International Education, 9(4), 356-371.

Windsor, D. (2009). Tightening corporate governance. Journal of International Management, 15(3), 306-316.

Wright, P. M., Dunford, B. B., \& Snell, S. A. (2001). Human resources and the resource based view of the firm. Journal of Management, 27(6), 701-721. 
Wright, P. M., \& McMahan, G. C. (2011). Exploring human capital: Putting 'human' back into strategic human resource management. Human Resource Management Journal, 21(2), 93-104.

Yeganeh, H. (2014). A weighted, mahalanobian, and asymmetrical approach to calculating national cultural distance. Journal of International Management, 20(4), 436-463.

Zhang, Y. (2013). Expatriate development for cross-cultural adjustment: Effects of cultural distance and cultural intelligence. Human Resource Development Review, 12(2), 177-199.

Zhang, Y., \& Rajagopalan, N. (2010). Once an outsider, always an outsider? CEO origin, strategic change, and firm performance. Strategic Management Journal, 31(3), 334-346.

Zucchella, A., Palamara, G., \& Denicolai, S. (2007). The drivers of the early internationalization of the firm. Journal of World Business, 42(3), 268-280.

Publisher's Note Springer Nature remains neutral with regard to jurisdictional claims in published maps and institutional affiliations. 